\title{
THE ANTECEDENTS OF CONSTRUCTION PROJECT CHANGE: AN ANALYSIS OF DESIGN \& BUILD PROCUREMENT APPLICATION
}

\begin{abstract}
Purpose: This research seeks to excoriate, define and delineate the main drivers of 'change' in commercial construction projects and generate guidelines on how to minimise exposure to the associated adverse effects upon project stakeholders.

Methodology: The research adopts mixed doctrines through a combination of epistemological lenses, embracing two primary philosophical stances: (i) interpretivism, to identify the primary drivers of change based on a systematic literature review and (ii) a post-positivist, inductive approach to analyse the results of change within a Joint Contracts Tribunal (JCT) Design and Build (D\&B) construction project case study.

Findings: The causal nexus of change during the construction phase is assessed and delineated; the key affecting factors are thematically grouped under headings: extent and severity; time in relation to implementing; instigating party; individual(s) responsible for managing the change; reason for the change; available resource; recoverable or non-recoverable; contract / project type; type of client. Following this, the effects of change on key elements of the project are encapsulated and recommendations for adaptations which may provide improved experiences are offered.
\end{abstract}

Originality: The study tackles the common issue of managing the deleterious effects of change on commercial construction projects, defining management techniques to minimise stakeholder tribulation.

\section{KEYWORDS}

Commercial construction; construction industry; change management; project rework; joint contract tribunal; design and build

\section{INTRODUCTION}

Change occurs in all industries albeit, the definitions of change, its impact and management procedures to mitigate risks differ across industrial sectors (Duncan, 2019). The word 'change' can be used as a verb or noun. The Cambridge Dictionary (2016) definition of the verb is "to exchange one thing for another thing" or "to make or become different." The noun definition is "the act of becoming different, or the result of something becoming different" (Cambridge Dictionary, 2016). Regardless of industrial setting, change is often resisted (Duncan, 2019). 
Reports show that the most successful companies utilise more than three times as many methods to engage the parties in change than unsuccessful companies (Meaney et al., 2008), suggesting a multi-pronged approach can lead to a more successful outcome with regards to change.

Within the construction sector, change can occur at any point throughout a project's lifecycle (Stasis et al., 2013). However, proactively managing and mitigating issues early in the process can protect a project from detrimental change effects during the construction phase (ibid). Despite extensive research conducted in this area, there are no effective or unique management methods available for avoiding and managing change (Okadaa et al., 2017). Alternative perspectives and approaches to change may however provide clients with flexibility and a more positive experience during the construction stage (McGraw Hill Construction, 2014). By focusing on the effects experienced during the construction period (and reviewing the causes and measures that could have been adopted during the earlier stages), a viable solution can be pursued.

Managing change during the construction stage tends to be resource-consuming in comparison to the process during the design stage, requiring examination of both the root cause and any potential effects (Stasis et al., 2013). Each change requires analysis and resolution, which is dependent on the relationship and communication between stakeholders. Often the main contractor is under pressure to juggle time, cost and satisfying client expectations (Okadaa et al., 2017). In recent years, there has been an increase in the number of contractors submitting overly competitive bids to win work with the intention of regaining losses through subsequent change orders, ultimately causing overruns on the programme and budget (ibid) or the use of change orders to make a D\&B project match the clients' actual requirements (Collins and Parish, 2014). This corporate behaviour has stimualted the increasing use of modern procurement methods rather than D\&B (Tilacz, 2008).

Against this industrial setting, this research aims to excoriate, define and delineate the main drivers of 'change' in commercial construction projects under Joint Contracts Tribunal (JCT) Design and Build (D\&B) main contracts. In doing so, the work generates guidelines on how to minimise exposure to the associated adverse effects upon project stakeholders. Concomitant objectives seek to: i) reduce the likelihood of change and as a consequence, the development of an adversarial relationship between project stakeholders; ii) ensure that projects remain 
profitable and disputes are minimised for the benefit of all stakeholders; and create a conceptual framework to guide future best practice in terms of minimising change and the detrimental effects of change within a project.

\section{METHODOLOGY}

The research adopts mixed doctrines through a combination of epistemological (Greene, et al., 2016) and deontological (Cavanaugh and Fastiggi, 2013) lenses, embracing two primary philosophical stances. First, interpretivism (Ryan, 2018) is used to manually analyse extant literature and identify the primary drivers of change and ultimately the effects on cost, time and quality on construction projects. This body of knowledge is utilised both when carrying out a systematic review of literature (where each publication represents a unit of analysis) and case study (where practitioners' insights and axiological perspectives will augment the literature reviewed) (Noor, 2008). There are limitations associated with an interpretivist approach. The empirical influence (Stahl, 2014) of interpretivism can drive confirmation bias; therefore, governance will be required to validate the research. The utilisation of a mixedmethods research via both literature review and case study, critically analysing the specific challenges on a project in both a quantitative and qualitative manner will ensure validation of the findings (Lucko and Rojas, 2010). Secondly, a post-positivist, inductive approach (Ryan, 2018) will be adopted to analyse the results change within a JCT construction project case study. This approach is adopted since a range of sources will be required to progressively establish a clear perspective of change management in practice. Documentation collected will include secondary data contained within change management reports available within the public domain - used to provide a broad overview of change management in theory. Primary qualitative (Trullols, et al., 2004) and quantitative (Haardörfer, 2019) data collected from a semi-structured survey (Schatz, 2012; Schmidt, 2004) undertaken with commercial construction practitioners - used to gain a deeper understanding of change management in practice. A case study (Noor, 2008) focusing on a specific change, reviewing the cause, effect and management processes carried out will allow an in-depth view of specific change items to be accrued. This process is adopted to complement the analysis of a variety of different sources - some of which will require subjective review whilst synthesising personal opinions in a social construct (Krippendorff, 2005) - refer to Figure 1.

< Figure 1 - Process Flow Diagram for the Research Approach Adopted. > 


\section{Methods Adopted}

With regards to methods and procedure, the following process was adopted over two phases. In phase one, a review of extant literature was implemented using bibliometric techniques (Wouters, 2015) such as VOSviewer and database searches using Web of Science and Scopus. First, key words were identified using a manual literature review of pertinent topics and issues, these key words were identified as (i) construction AND; (ii) change management AND; (iii) rework AND; and (iv) change process. Once identified, the key words were entered into Web of Science and Scopus using the TITLE-ABS-KEY to download a txt. file of publications that were then entered into the bibliometric software tool VOSviewer. VOSviewer which is an acronym for "visualisation of similarities" is a tool for creating visual bibliometric networks, which can include a cornucopia of different publication types, and can be developed based on the characteristics of the publications used (Roberts, et al., 2019). VOSviewer is also capable of 'text mining'; a function where key terms can be defined and extracted from a body of literature (Leiden University, 2019). Databases such as Scopus and Web of Science can be used to feed information into VOSviewer to create visual networks (Jeong and Koo, 2016). The purpose of conducting this systematic literature review was to identify what the primary causal factors of the changes under investigation were. Once identified and delineated, the second phase of the research could be conducted.

The second phase involved an exploratory, semi-structured interview process (Adams, 2015), where three sets of questions were produced to target three bands of respondents: (i) general questions regarding change management in construction; (ii) questions surrounding construction change management on a specific project; (iii) questions surrounding a specific change on the case study project(refer to Table 2). The case study was conducted on a private sector commercial new build project located in an inner-city Midlands region, UK - the project value was circa $£ 50 \mathrm{~m}$ and project duration just under two years. Changes occurring during the construction phase accounted for a circa $12 \%$ increase to the project value. Participants for the interviews and case study include key project team members from the Employer's team (Professional Quantity Surveyor); Main Contractor's team (Project Director, Quantity Surveyors, Project Managers); and supply chain (Sub-Contractor representative). Recordings of the interviews were taken using a Dictaphone and later an intelligent verbatim transcription style adopted (Henderson, 2016). Due to the commercially sensitive nature of this research, a strict ethical procedure was adopted throughout the process. This entailed guaranteeing strict anonymity to all participants and assurances that all information gathered would: not be 
divulged or disseminated to any third party willingly or otherwise; and be securely destroyed post the investigation (Fisher et al., 2018). Before interviews took place, an explanation of the research proposal, aims and objectives was provided, and a consent document was signed by each interviewee to secure their participation but also explain that they could withdraw from the research at any stage of the process (Morrison and Sacchetto, 2018).

\section{ANALYSIS OF CHANGE IN COMMERCIAL CONSTRUCTION PROJECTS}

Change occurs in all sectors but management procedures and effects vary across differing industries. Change in the legal industry for example, is often resisted (Duncan, 2019). McKinsey's survey of business executives demonstrated that despite the implementation of numerous change management strategies to businesses, only $30 \%$ proved successful (Meaney, et al., 2008). Change in the engineering sector is defined as any modification to elements, drawings, software that were previously provided during the design and production processes regardless of the scale or type (Jarrett, et al., 2011). In engineering, a change can include any modification applied to "form, fit and/or function of the product as a whole or in part" (ibid) and can lead to further adjustment to any interacting or dependent elements. In construction, a change constitutes any alteration to the scope, period, cost and/or quality of the contracted works (Ibbs, 2007). Hence, the definition of change varies between sectors - refer to Table 1 .

< Table 1 - Definitions of Change >

For this research, the term 'change' is used to describe any variation to a construction project's contract baseline. This includes anything which effects the design, scope, specification, cost and time elements of a project from that which is defined within the contract. The term 'stakeholder' also has varying meanings in relation to construction projects (Bahadorestani, et al., 2019) but for this research the term describes (i) Employer; (ii) Employer's Agent; (iii) Main Contractor; (iv) Supply Chain; (v) End User; and (vi) Designers and Consultants.

\section{Change Management within the Construction Process}

The Royal Institute of British Architects (RIBA) plan of work, 2013 sets out eight stages of a construction project lifecycle from project conception to post-completion (RIBA, 2013) but for this paper, stage five, "Construction" will be the focus (refer to Figure 2). 
< Figure 2 - RIBA Plan of Work Stages Demonstrated (Royal Institute of British Architects, 2013)>

Changes in construction can occur at any point throughout a construction project's lifecycle. It is important that detrimental variations are proactively managed and mitigated early in the design process, deeming the design phase as the most pertinent time to induce action (Stasis, et al., 2013). Love et al. (2016) discusses rework in construction, and its continuation as a persistent issue. Rework can be defined as re-doing activities or processes that, had they been implemented correctly in the first place, would not have needed to be readdressed (Love, 2002); omissions, changes and errors in design and construction all fall under this definition. However, others have used 'rework' to describe the direct cost from any work which is redone locally, regardless of the initial cause (Robinson-Fayek, 2003) but excludes change orders and errors in off-site fabrication (Robinson-Fayek, 2003).

Despite extensive research from organisations such as Chartered Institute of Building (CIOB) and Construction Industry Institute (CII) on change management in construction "no unique method is available for avoiding or managing them effectively" (Okadaa, et al., 2017). Literature provides positive recommendations for project managers to embrace and utilise variations to their benefit wherever possible, suggesting past projects can be used for the lessons learnt process, minimising negative impacts and maximising the benefits of necessary changes (Ibbs, 1997). However, adopting this mentality can be difficult considering how time consuming the management of change can be (Stasis, et al., 2013). The McGraw Hill Smart Market Report aims to provide an optimistic view of change in construction projects by emphasising a non-negative perspective as opposed to a positive perspective (McGraw Hill Construction, 2014). Change orders provide a client with the flexibility to adjust or improve the contracted project, the McGraw Hill Smart Market Report urges stakeholders to review their perception and adjust their focus to utilising change as a means for avoiding and mitigating issues (McGraw Hill Construction, 2014).

\section{Change Management and Causes of Change in the Construction Phase of a Project}

\section{Lifecycle}

Managing change procedures during the construction stage requires examination of both the root cause and any potential effects of the change (Stasis, et al., 2013) in a live scenario, making 
it an intense process, with every moving targets. Indirect rework, which includes all works required to take place in order for the direct rework activity to fit with the unaffected design and/or construction, can increase the cost of the rework by as much as six times the direct rework cost (Love, 2002).

There are many causes of rework, providing a number of ways to categorise the causes of change. The primary causes can be categorised as being driven by four key parties: (i) The client - changes initiated by the client for a change to the employer's requirements as defined within the contract; (ii) consultants - changes initiated by consultants such as design consultants, fire strategy consultants, etc; (iii) contractor - changes initiated by the Contractor, this could be to save on cost or time, or to improve quality or buildability; (iv) and others changes initiated by other parties, such as the end user, sub-contractors, planning department, etc. (Hwang, 2014). Alternatively, Okada et al. (2017) defines construction stage changes in three main categories: (i) unforeseen conditions; (ii) design errors and omissions and (iii) owner-driven changes (Okadaa, et al., 2017). There are numerous reasons for client driven changes including advancements in technology, new leadership or policy (Ibid). Each change requires consideration and conclusion, the method of which is dependent on the relationship and communication between stakeholders. There is often pressure on the construction company with juggling time, cost and keeping the client satisfied (Ibid).

With regards to project change in relation to the contract type, it is proposed that some contractors provide under-priced bids to secure a project, later recovering the lost value by driving project change, leading to late handover of the project and an overrun on the budget (Okadaa, et al., 2017). It is also discussed by Collins and Parish (2014) that change orders are required to make a Design Bid Build (DBB) project match the clients' actual requirements (Collins and Parish, 2014). Modern procurement methods such as Construction Management Risk (CMR), Integrated Project Delivery (IPD) are becoming increasingly popular options over DBB, as a result of DBB being generally considered flawed (Tilacz, 2008). It was concluded by Collins and Parish (2014) that owner requested changes on the DBB case study project they examined, could have been largely mitigated through the use of an IPD project due to the early involvement from the client, leading to a lesser requirement for change in order to meet their needs after the contract has been set (Collins and Parish, 2014). Items from lessons learnt and best practices reviews following the completion of a project can be split into three categories viz: (i) planning; (ii) design and management; and (iii) construction (Okadaa, et al., 2017). 
Further analysis on: "the impact of owner-requested changes and possible prevention and mitigation strategies is needed" (Okadaa, et al., 2017).

\section{BIBLIOMETRIC ANALYSIS OF LITERATURE}

The search terms used in the Web of Science search were (i) construction; and (ii) change management; or (iii) project rework; or (iv) change process. By using VOSviewer merged with Web of Science or Scopus, patterns can be developed. Following a search of documents with a title relating to construction change management or rework from 1970 to 2019, there are eight key authors which emerge: (i) Peter Love; (ii) Lieyun Ding; (iii) Fran Ackermann; (iv) Jim Smith; (v) Zahir Irani; (vi) Hanbin Luo; (vii) Welli Fang and (viii) Jane Matthews; all of which are linked to Peter Love - refer to Figure 3.

< Figure 3 - Leading Authors in Change Management VOSviewer Screenshot (CWTS, 2019)>

Further analysis into the bibliometric data demonstrates the different industries researching construction change over the past fifty years - refer to Figure 4. Three sectors are predominantly conducting the most research in change and project rework, namely: (i) Engineering Civil (frequency $(f)=252$ or $28.57 \%$ ); (ii) Construction Building Technology $(f=$ 185 or 20.97\%); and (iii) Engineering Industrial $(f=159$ or $18.02 \%)$ (Clarivate Analytics, 2019). This demonstrates that although change is heavily debated within the construction and civil engineering literature (at 49.54\%), all other industrial sectors account for the other half of the volume of research conducted. Because the construction sector contributes to $6 \%$ of the UK economy (House of Commons, 2019) one can deduce that change within the construction and civil engineering sector is comparatively disproportionately high and this is perhaps attributable to the bespoke nature of construction projects (Blismas, et al., 2011) and an often ill-informed client (Gamil and Rahman, 2017). This would perhaps explain why a Web of Science search using the same keywords illustrates that the general trend of research in the area has almost increased linearly between 2000 to 2019 (refer to Figure 4) - this represents a sixfold increase in publications over these two decades.

$<$ Figure 4 - Web of Science Analysis of Construction Change Research Over Time (Clarivate Analytics, 2019) > 
A further analysis into the key terms featured in the publications can be produced through VOS viewer - see Figure 5. Three main clusters of terms have been identified viz: (i) research related terminology - red; (ii) terminology related to change management - green; and (iii) change process related terminology - blue.

\section{$<$ Figure 5 - Analysis of Key Terms of Construction Change Research with Fifty Occurrences (CWTS, 2019) >}

The three most prominent terms are: (i) construction; (ii) change; and (iii) process, all of which are featured on cluster three illustrating the inherent interconnectivity between managing the process of change within construction activities on site. Figure 6, features terms that have a frequency of ten times or more to create a more detailed picture of key terminologies investigated. Five main clusters have formed viz: (i) red - terms such as delay, conflict, cost overrun and negative impact, providing an indication of the negative effects of project change; (ii) yellow - terms such as collaboration, innovation, commitment and successful implementation, providing a much more positive outlook on construction change management; (iii) blue - terms such as area, period, type, year, region, suggesting this cluster relates to project characteristics and its influence on change outcomes; (iv) purple - terms such as plan, assessment, control and consideration, suggesting this cluster relates to the control mechanisms associated with change management; (v) green - terms such as organizational change, education, theme, transformation, which indicates this cluster relates to the post-completion perspective of change.

$<$ Figure 6 - Analysis of Key Terms of Construction Change Research with Ten Occurrences (CWTS, 2019) >

\section{INTERVIEW ANALYSIS}

Twelve semi-structured interviews were conducted with a variety of construction practitioners with differing perspectives, backgrounds and years of experience - See Table 2. Each of the respondents answered questions on their general experience regarding change. Those involved in a specific project then answered questions about change within the context of their specific project. Those also involved in a specific aspect of change went on to answer questions about the details of that change - See Appendix 1. The three sets of questions were developed in order to target both site-based project staff, as well as high-level management. The additional 
two sets of questions also provided the opportunity to cross-examine responses based on general experience and specific experiences.

<Table 2 - Respondent Demographic>

\section{<Appendix 1 - Interview Questions>}

The responses from each of the practitioners interviewed were split into three categories based on their role: (1) commercial - defined as site based commercial staff such as quantity surveyors of varying levels; (2) operational - defined as site based operational staff such as main contracting project managers; (3) management - defined as office based practitioners who manage high level, or business focused operations rather than day-to-day site processes. The responses from each of the three categories were then analysed and summarised - See Table 3.

The analysis was conducted in a methodical manner: (i) the interviews were conducted oneon-one and face-to-face with Dictaphone recording, providing the opportunity to ask additional questions where necessary to further clarify a response; (ii) the recordings were then listened to and transcribed using intelligent verbatim transcription style (Henderson, 2016). This provided the opportunity to re-attend each answer provided, numerous times during the transcription process. (iii) once all responses were transcribed, the transcripts were examined and summarised for each respondent; (iv) each respondent was then categorised by role and each category of respondents' encapsulated answers were further examined for patterns and repetitions throughout each category to form table 3, which epitomises each category's key points.

< Table 3 - Qualitative Analysis of Responses Categorised by Discipline >

\section{Cause and Effect of Change During the Construction Stage}

The responses showed that the effect of a change is generally dependent on several factors See Figure 7. As demonstrated within figure 7, some consistent themes were developed as key affecting factors:

(i) Extent and severity - The impact of a change is largely dependent on the severity and extent of the change taking place, respondent $\mathrm{R} 1$ noted that:

"It will be a case of the extent of the change, if it's ... a large change it's going to have a financial impact, a programme impact, and obviously whether it can be done. You've 
got to go out and get costs for that change, have that cost approved, factor it into our overall programme, so it causes quite a knock-on effect, depending on ... the severity of the change"

The comment provided by respondent R1 sums up the consensus, which led to the extent and severity of a change being deemed the factor most influential on the outcome.

(ii) Time in Relation to Implementing - When discussing the effect of change, respondent R2 said:

"The effects would be different depending on when the change was instructed in relation to when that element of change needs to be carried out"

Respondent R6 noted:

"If it's a change to the finishes when we are in the ground then it's not really a problem, we have sufficient time to look at the change, get it priced properly, get it agreed before we move forwards on it."

The comments surrounding time in relation to implementing the change were common to all respondents, making time the second most influential factor.

(iii) Instigating Party - Respondent R6 commented:

"Depending on whether it's a clear client driven change, ... it's usually relatively straightforward to agree something with a client, if it's not something that's relatively straightforward then obviously you get into a situation where you're spending time negotiating on costs and potentially getting into an argument with the client at a stage where you probably don't want to be."

Respondent R4 continued:

"Usually, if you've got an experienced client they know if they are instructing a change with a knock-on effect but sometimes you work with clients who are very set in their way with a set budget and they probably don't appreciate what they are changing."

Respondent R4's comments were in line with the feedback provided generally, affirming the party responsible for instigating a change as a key influential factor impacting change. (iv) Individual(s) Responsible for Managing the Change - R12 commented on the effect the people managing a change can have:

"It's who is dealing with it ... how an employer handles the change; how a project manager handles it; how a contractor handles the change. So, change can be different from project to project on the basis of those different people"

R12's response was in accord with the overall response, deeming the individual(s) responsible for managing change as a key influential element. 
(v) Reason for the Change - respondent R2, when discussing change which is driven by an alteration in specification with no benefit to the quality, cost, time or buildability, provided the following comment:

"It's a bit soul destroying doing an element of work and then having to remove it all and do it again"

Similar to R2 above, respondents suggested that the motivation for change had a bearing on the result of the change. This has a flow-on effect on those carrying out the work and thus on the subsequent quality of the work achieved.

(vi) Available Resource - Participant R4 summed up the consensus when asked how well we manage change as an industry:

"I don't think we really truly capture time implications relating to change. I think that is driven in large by a lack of operational input in relation to that change and probably a lack of knowledge in what's changing."

Commonly expressed throughout the interviews was the notion that resources available to manage and review a change have a significant bearing on the overall effect of a change.

(vii) Recoverable or Non-Recoverable - R4 noted that:

"There's change upstream with ... client driven change, which is good and generally recoverable on time and programme, and then there is sub-contract change, which is generally disastrous, which is not recoverable on programme or cost."

Respondent R4's comment conforms to the comments seen across the board, demonstrating that whether a change is recoverable or not can have an impact on the result.

(viii) Contract / Project Type - R9 summed up the general responses when discussing the effects of change:

"Change during the construction phase, depending on the type of project and the type of contract, which has an influence on whether it is a positive or negative effect. So, if it is a 'Traditional' contract where the change is led by the client, as a main contractor or sub-contractor, you are entitled to recovery of time and monies and able to manage the process in a full and proper way then it can be positive. If the change is on a 'Design and Build' then the change is led by ... the main contractor or sub-contractor and is led by financial constraints, I.e. value engineering a situation because we need to overcome a financial situation, then it can be negative and can lead to what appears to be a short term positive result but often leads to a long term negative result."

The point provided by $\mathrm{R} 9$ is also repeated by others, making the type of contract or project a factor which has a significant bearing on the result of a change.

(ix) Type of Client - Respondent R7 commented: 
"In places like hospitals where technology moves quite quickly, those changes can be significant in a timescale like that because machines can change, policy changes or there are all sorts of things that might change the design"

Similar to respondent R7, the respondents agreed that the type of client, in terms of which sector, their priorities and the resources available to them place the type of client as one of the key factors affecting change.

<Figure 7 - Factors Affecting the Impact of Change with Frequency of Remarks>

\section{Drivers of Change}

All respondents noted client-driven changes to be the main driver when discussing the causes of change. Designer-led changes were noted by $70 \%$ of respondents; and end-user directed changes were raised by $60 \%$ of respondents. Whilst the respondents agreed that these were the three most prominent instigators of change, some went on to discuss what drove the parties to prompt change. As noted by respondent R7 above, this can be through a change in requirements, such as technological developments during the design and construction phases. All management respondents had a comparable view on the root changes, as summed up by respondent R11:

"Poor or inadequate design, an inadequate brief, lack of understanding of practicalities from the consultants and designers... I think the reality is that designs are never thought through or concluded to a point where you can satisfactorily let a project, because of timeliness, in a manner that you are totally comfortable that the end-product is going to be in line directly with the tender and the contract that you let"

Within the interview, respondents were asked to complete two Likert scales based on their general experience on past and present construction project change; one of which was regarding the parties likely to instigate change and the level of control they are likely to have over the result of the change. - See figure 8 . The overall response shows, except for the employer and project manager/employer's agent, a correlation between the likelihood of the party to instigate change and the control said party has over change. In the case of the employer and project manager/employer's agent, both parties were deemed to have a higher level of control over change than likelihood to initiate change, albeit the employer was still deemed to be the third most likely party to initiate change. 
< Figure 8 - Comparison of Overall Practitioners' Ranking of Parties' Control Over Change vs The Likelihood of Each Party to Initiate Change >

\section{The Effects of Change on Key Elements of a Project}

The respondents completed a Likert scale, which looked at the main elements affected by change: (1) Financial; (2) Programme; (3) Quality; (4) Relationships; (5) Safety. Respondents rated the general effect change during the construction phase can have on each of the elements and ranked them in order of importance. The results have been summarised in figure 9.

< Figure 9 - Comparison of Overall Practitioners' Ranking of Importance vs The Effects Imposed by Change on Each Element >

When looking at the overall results in Figure 9, the comparison between importance and effect appears generally relative except for the programme and relationship elements. The information suggests relationships may be inadvertently more positively affected than the focus from those dealing with change management intends. The programme, however, appears to be more negatively affected than the consensus suggests it should be. An increase in operational input to change management processes, or through refocusing commercial teams' priorities could improve the effect change during construction has on the programme.

For operational staff, change was deemed to be the cause of confusion and stress when instigated late in the process. In cases where change is instigated late in the process, ie during the physical works on site of after the works have taken place, the workforce often become incredibly demotivated by the imposition of abortive works and unnecessary rework, leading to a decrease in quality when carrying out the change. Respondent R10 commented:

"When you try and instil late change ... its human nature to be in a position where once you start doing something different from what you'd planned and set out to do, the closer you get to doing it the worse you're going to feel about it. You get demotivated and it has a massive impact on quality."

The respondents commented on the cost of change which has occurred during the construction phase, respondent R11 summed up the consensus with the following comment:

"Change will result in the cost outweighing the benefit because you are no longer in a competitive tender environment, you are at the behest of the contractor or the developer who has no longer got to compete with the pricing associated with the change and that's where everybody makes an extra few pence on the pound." 
Not only does the physical cost of a change during the construction phase amount to more than it would have had it been implemented during the design, but the added workload imposed on those involved leads the preliminary costs to increase also. Respondent R8 described some of the inadvertent effects in the following statement:

"An increase in cost may occur due to the cost of the change itself and the potential for prolongation cost, disruption costs and other heads of claim of loss and expense i.e. loss of overhead potential, loss of profit, preliminaries thickening, change of conditions, inflationary increases, financing etc"

The responses suggested that oftentimes, clients may not understand the full implications of the change they are requesting on both time and resource, respondent R3 commented:

"People see change as making money but then they ... end up losing money because they don't understand the changes that they have made."

This gap in understanding could be the cause of the negative association with change during the construction phase.

All respondents explained that safety should never alter; despite change, the standards of safety should always remain high and form part of the assessment whenever a change is imposed.

\section{The Impact of the Individuals Managing the Change and Their Expertise and Priorities}

The standard of change management is dependent on the individual managing the change; usually the quantity surveyor takes a leading role in change management, which may explain why financial impacts are deemed the best supported element. Respondent R4 commented:

“We generally are pretty good at it from a financial point of view. I don't think we really, truly capture time implications relating to change. I think that is driven in large by a lack of operational input in relation to that change and probably a lack of knowledge in what's changing we are too busy trying to build instead of looking at the wider picture and then it's often too late."

It was highlighted that there was a lack of operational input throughout change management process. The lack of technical knowledge of the quantity surveyor forces assumptions, which leads to errors forcing the operational team to working harder and longer to overcome resulting delays. When asked what the immediate effects of change were, operational responses generally resembled the response from respondent R7:

"Generally, from my perspective it's negative. It disrupts your programme, plan, process and you've got to stop and think and do something different so generally that's the impact of it." 
It was estimated by the commercial respondents that, in general, between $30-60 \%$ of a quantity surveyor's time during a live project can be spent managing change, making it a core part of the quantity surveying role. Respondent R12 commented when discussing a specific project:

"My whole role on that project was primarily looking after changes, it employed me for two years to look after the changes."

Whilst the parties agreed that change management forms a core part of the quantity surveying role. Through a review of the language used in some of the UK's leading contractors' (Price, 2019) job descriptions for quantity surveying roles of varying levels, it was determined that out of the eight documents reviewed, change management was not mentioned at all. Instead the key terms included (1) project; (2) commercial; (3) experience; (4) team working - See Table 4.

<Table 4 -Analysis of Leading Contractors' Quantity Surveying Role Descriptions>

As established above, the quantity surveyor is likely to have the most input when assessing change, which may explain why the element within figure 9 considered as most important to the commercial respondents, financial, was also demonstrated as being most positively affected by change. It may also explain why the programme element, which was ranked most important by the operational respondents but second to least important by the commercial respondents, was deemed by all disciplines to be negatively affected by change. The information suggests that the lack of operational input in change management may be the cause of the detrimental effect on the programme since programme was thought to be of low importance to the commercial respondents who seemingly carry out most of the change management procedures, and those who rank the programme as important are seemingly not providing the level of input required as noted by respondent R6:

"It's about being more joined up across the disciplines in terms of commercial, operational, design management. Our operational staff work on the programmes to build and get the job completed, whereas it might be better to involve them slightly differently and to be making sure that we are recovering cost and time if we need to be.

I think it's just more about understanding each other's roles a bit more and working together"

When discussing how well change is managed in general terms throughout the industry, respondents had varied opinions, but all disciplines noted that financial implications were better recovered than any other aspect. Respondent R12 noted: 
"The quantity surveyor has got a massive role in terms of tracking things and making sure the instructions are received... I just think it's a massive thing that you have the ability of making sure ... you have one clear place where all of that change is able to be viewed and understood, where we are with the parties within the process."

Operational responses suggest they are more likely to proceed in the interest of progressing the project and on a trust basis, whereas commercial responses suggest a stance which protects the contractual position of their employer. Respondent R2, an operational practitioner, said:

"I've been caught out by being too friendly with change and going on someone's word and sometimes if they see you implementing the change before they instruct it they can hold back a bit and then they can let you do it at risk."

To improve change management practices, it was suggested that firstly the volume of change during the construction stage should be minimised to a manageable capacity. Respondent R11 summed up the consensus:

"We are a very complex industry, we don't turn out the same component on a workbench inside a factory day in day out, it's very complicated what we do and most buildings are bespoke designs by people that don't really understand the construction process, and therefore you're always going to have an element of error and change... so I think because of that we are an industry that manages change well. I think the question is do we have too much change."

Whilst it was recognised that change is inevitable and required, the respondents were unified in their feedback suggesting that there is too much change.

\section{FINDINGS AND DISCUSSION}

\section{The Root of the Problem}

The overriding insight taken from the interview responses is that the definition of the brief in the very early stages of a project will influence the quality of the design. The brief and design collectively influence the quality of the bid produced by the feasibility team and later the contractor. In the absence of a fully considered brief, lacking input from all stakeholder parties, the developed design becomes sub-optimal and flawed. Amendments and change, along with associated costs and inconvenience, become inevitable.

And since change is inevitable, remedial measures become more or less effective as a function of how quickly corrective measures are initiated. The earlier a change is dealt with, the more time is available for the parties to assess the implications of the change and reduce stress and confusion on site. If the industry knows change is unavoidable and practitioners appreciate that 
change identified early in the process is more likely to lead to successful outcomes, the question must be asked, why is so much change encountered so late in the process?

In instances where change is accurately monitored, and sufficient resources and time allocated to manage alterations, change management is deemed successful overall. However, it is rare that enough time is allowed for effective change management to take place; usually due to poor risk allocation and onerous tendering conditions. More often, the fast-moving nature of construction leaves project professionals out of their depth: (1) designers and consultants with insufficient construction knowledge produce design developments that are flawed in practice; (2) quantity surveyors evaluating the implications of a change do so without expert input on buildability and scheduling practicalities; (3) pressure on the operational team to progress the works are set at odds with the contractual status of the change.

\section{The Effects of Change Initiated During the Construction Stage}

The long-term effects of change which occurs during the construction stage are dependent on several influential factors. Ultimately, where change has occurred during the construction phase, the costs will certainly be higher than if the change had been embedded within the original design. Along with every change, no matter how small, comes additional work, which takes additional time. Even in cases where elements are simply omitted, there is additional workload in managing and implementing the change itself and the mindset of those involved in implementing the change. This leads to disruption and additional pressure on the programme and workforce. The result of this is that despite client-driven aspirations to improve the quality of a project post-design, the reality is that changes in and of themselves can lead to an undermining of the project quality outcomes. Change creates added pressure and demotivation whenever work rhythm, schedules and corrective or abortive disruptions are called for. In turn, this leads to demotivation of the work teams with less effort being afforded to subsequent works.

Relationships can be affected positively or negatively depending on how well the changes are communicated and managed. In cases where a contractor uses change as an opportunity to communicate and build on the relationship with the client and supply chain, the relationship should benefit, but only provided the changes are managed well and are implemented successfully. In cases where contractors or sub-contractors communicate poorly or use change 
as an opportunity to extract profit or recoup time to offset earlier delays, relationships will inevitably diminish along with trust.

\section{CONCLUSION AND RECOMMENDATIONS}

This study confirms that change management is a core part of the quantity surveying role, yet typically doesn't appear on formal role descriptions. The inference is that companies do not recognise the significance of the change management function and this is why it is not proactively dealt with. While business management theory recognizes the importance of change management, particularly in reference to the role of the quantity surveyor, there is a clear discontinuity between hypothetical recognition of the issue and practical adoption of procedural change management measures.

Aside from the quantity surveying role, failures in change management are attributable to a lack of proper input from all stakeholders to a project; and especially to operational and design management personnel. This study particularly spotlights the hitherto unestablished impact of these roles in the change management process of projects. As with quantity surveyors, change management is not incidental but central to the professional function of designers and builders, and that responsibility must be undertaken in a structured rather than an ad hoc manner if projects are to be delivered on time and to quality under conditions of uncertainty and change that characterize building works today.

\section{Closing the Gap in Knowledge and Understanding}

By consulting with both designers as well as construction practitioners, project briefs are more likely to be developed with greater accuracy, and with less risk of uncertainty and misinterpretation. Similarly, when designing a scheme, designers ought to consult with contractors as they liaise with clients. Full involvement of all principal parties to a project from the outset will greatly enhance minimisation of misinterpretations that are the typical later catalyst to project changes and escalating cost and time blow-outs.

Once reaching the construction stage, thorough, visual presentations and constant communication with the client and end user, demonstrating the proposed product, the level of late changes should decrease as expectations would be managed appropriately. Input from all affected parties, such as the client, designer, operational consultants, and commercial teams, when resolving change management issues, would improve success. 


\section{Setting Up for Success}

When setting up a contract, risk should be allocated to the party most equipped to manage each specific risk rather than overloading any one party. This only ultimately sets up the weaker stakeholder to fail, diminishing overall project success for all.

In the early stages of a project, clear communication from the supply chain and contractor to the client, end user and designers regarding the impact of late changes on time, cost, quality and morale could guide those most likely to drive change to a better understanding of the impacts. By demonstrating how a change is processed and managed by those responsible for carrying out the change, more focus may be seen to close out changes earlier in the development of the project.

\section{Process Management}

Full and sufficient record keeping is deemed essential in change management, and the impacts of any given change should be assessed at the earliest opportunity to avoid neglect or oversight of the issue. A clear, standardized yet versatile process for change management, should able to be applied to any change which may arise, would benefit all project stakeholders when dealing with change during the construction project.

The challenge is in obtaining requisite buy-in from responsible stakeholders for managing the change and to follow and maintain the process. A guidance model for the change management process has been developed and can be seen in Appendix B.

\section{Limitations and Future Research}

The research offered is indicative rather than definitive of the causal nexus of change and good practice management procedures. This is largely due to the small sample size of interviewees and its heavy representation of main contractor practitioners. Thus, the recommendations lend themselves to the main contractors. Further research into change management from the perspective of sub-contractors, designers, employers or other stakeholders may produce nuance to the current results. Another restriction of the research is the predominantly qualitative nature of the study; no analysis of the actual cost or time implications of change have taken place, making the nature of the study somewhat speculative. Further, quantitative analysis into the impact of change taking place during the construction phase may provide more structure to the research and aid buy-in from construction companies on development within the industry. 


\section{REFERENCES}

Adams, W., 2015. Conducting Semi-Structured Interviews. In: K. E. Newcomer, H. P. Hatry \& J. S. Wholey, eds. Handbook of Practical Program Evaluation. Hoboken: Jhn Wiley \& Sons, Inc., pp. 492-505.

Bahadorestani, A., Karlsen, J. \& Farimani, N., 2019. A Comprehensive Stakeholder-Typology Model Based on Salience Attributes in Construction Projects. Journal of Construction Engineering and Management, 145(9).

Balfour Beatty PLC, 2020. Senior Quantity Surveyor. [Online] Available at: https://www.balfourbeattycareers.com/job-detail?detail=uk15109-senior-quantitysurveyor [Accessed 14 March 2020].

BAM Construct UK, 2020. Project Surveyor. [Online] Available at: https://jobs.bam.co.uk/vacancy/project-surveyor-1722/1748/description// [Accessed 14 March 2020].

Blismas, N. G., Pendlebury, M., Gibb, A. \& Pasquire, C., 2011. Constraints to the Use of Offsite Production on Construction Projects. Architectural Engineering and Design Management, 1(3), pp. 153-162.

Cambridge Dictionary, 2016. Change meaning in the Cambridge English Dictionary. [Online] Available at: https://dictionary.cambridge.org/dictionary/english/change

Cavanaugh, T. A. \& Fastiggi, R. L., 2013. Deontological Ethics. In: New Cathollic Encyclopedia Supplement 2012-2013: Ethics and Philosophy. Detroit, MI: Gale, pp. 369370.

Clarivate Analytics, 2019. Web of Science. [Online] Available at: https://wcswebofknowledge-

com.ezproxy.bcu.ac.uk/RA/analyze.do?product=WOS\&SID=C1EPCBfxXIBqhFGWF $\underline{\text { Hu\&field=TASCA_JCRCategories_JCRCategories_en\&yearSort=false }}$ [Accessed 9 December 2019].

Collins, W. \& Parish, K., 2014. The Need for Integrated Project Delivery in the Public Sector. Construction Research Congress, pp. 719-728.

CWTS, 2019. VOSviewer Bibliometric Analysis of Authors in Change Management, Leiden: CWTS.

Duncan, S. S., 2019. Change Management: For Law Firms, A Particular Challenge. Of Counsel; New York, pp. 8-11.

Fisher, L., Edwards, D., Parn, E. \& Aigbavboa, C., 2018. Building Design for People with Dementia: A Case Study of a UK Care Home. Emerald Insight, 36(7/8), pp. 349-368. 
Galliford Try Holdings plc, 2020. Quantity Surveyor - Building East Midlands (Wolvey). [Online] Available at: https://gallifordtry.taleo.net/careersection/gtexternal/jobdetail.ftl [Accessed 14 March 2020].

Gamil, Y. \& Rahman, I. A., 2017. Identification of Causes and Effects of Poor Communication in Construction Industry: A Theoretical Review. Emerging Science Journal, 1(4), pp. 239-247.

Greene, J. A., Sandoval, W. A. \& Bråten, I., 2016. Handbook of Epistemic Cognition. New York: Routledge.

Haardörfer, R., 2019. Taking Quantitative Data Analysis Out of the Positivist Era: Calling for Theory-Driven Data-Informed Analsis. Health, Education \& Behaviour, 46(4), pp. $537-$ 540.

Henderson, H., 2016. Difficult questions of difficult questions: the role of the researcher and transcription styles. International Journal of Qualitative Studies in Education, XXXI(2), pp. 143-157.

House of Commons, 2019. Construction industry: statistics and policy. London, House of Commons Library.

Hwang, B.-G. Z. X. a. G. K. J., 2014. Investigating the client-related rework in building projects: The case of Singapore. International Journal of Project Management, pp. 698708.

Ibbs, C., 1997. Quantitative Impacts of Project Change: Size Issues. Journal of Construction Engineering and Management, pp. 308-311.

Ibbs, W. N. L. L. S., 2007. Quantified Impacts of Project Change. Journal of Professional Issues in Engineering Education and Practice, pp. 45-52.

Jarrett, T. A. W., Eckert, C. M. \& Caldwell, N. H. M. a. C. P. J., 2011. Engineering change: an overview and perspective on the literature. Research in Engineering Design, pp. 103-124.

Jeong, D.-h. \& Koo, Y., 2016. Analysis of Trend and Convergence for Science and Technology using the VOSviewer. International Journal of Contents, XII(3), pp. 54-58.

Joint Contract Tribunal, 2016. JCT Design and Build Contract 2016. London: Thomson Reuters (Professional) UK Limited.

Kier Group Plc, 2020. Quantity Surveyor. [Online] Available at: https://kier.referrals.selectminds.com/jobs/quantity-surveyor-9441 [Accessed 14 March 2020].

Krippendorff, K., 2005. The Social Construction of Public Opinion. Wiesbaden: VS Verlag für Sozialwissenschaften. 
Laing O'Rourke, 2020. Senior Quantity Surveyor. [Online] Available at: https://career.laingorourke.com/jobs/vacancy/senior-quantity-surveyor-

0170/188/description/ [Accessed 14 March 2020].

Leiden University, 2019. Welcome to VOSviewer. [Online] Available at: https://www.vosviewer.com/

Love, P., 2002. Auditing the indirect consequences of rework in construction: A case based approach. Managerial Auditing Journal, pp. 138-146.

Love, P. E. D., 2002. Influence of project type and procurement method on rework costs in building construction projects. Journal of Construction Engineering and Management, pp. 18-29.

Love, P. E. D., Edwards, D. J. \& Smith, J., 2016. Rework causation: emergent throretical insights and implications for research. Journal of Construction Engineering and Management, p. 1943.

Lucko, G. \& Rojas, E. M., 2010. Research Validation: Challenges and Opportunities in the Construction Domain. Journal of Construction Engineering and Management, pp. 127135.

Mach, L., 2019. MEASURING AND ASSESSING THE IMPACT OF THE GLOBAL ECONOMIC CRISIS ON EUROPEAN REAL PROPERTY MARKET. Journal of Business Economics and Management, 20(6), pp. 1189-1209.

McGraw Hill Construction, 2014. Managing Uncertainty and Expectations in Building Design and Construction, n.k.: McGraw Hill Construction.

Meaney, M., Pung, C. \& Kamath, S., 2008. Creating Organizational Transformations. The McKinsey Quarterly, n.k. July, pp. 1-7.

Morgan Sindall Group, 2020. Vacancy Details. [Online] Available at: https://ats.morgansindallgroup.com/VacancyInformation.aspx?VId=67536 [Accessed 14 March 2020].

Morrison, C. \& Sacchetto, D., 2018. Research Ethics in an Unethical World: The Politics and Morality of Engaged Research. Work, Employment and Society, 32(6), pp. 1118-1129.

Noor, K. B. M., 2008. Case Study: A Strategic Research Methodology. American Journal of Applied Sciences, V(11), pp. 1602-1604.

Okadaa, R. C., Simonsa, A. E. \& Sattinenia, A., 2017. Owner-requested Changes in the Design and Construction of Government Healthcare Facilities. Primosten, Procedia Engineering, pp. 592-606. 
Price, D., 2019. CN100 2019: The top 100 UK contractors. [Online] Available at: https://www.constructionnews.co.uk/financial/cn100-2019-top-100-uk-contractors-0509-2019/ [Accessed 16 March 2020].

Roberts, C. J. et al., 2019. Post-occupancy evaluation: a review of literature. Emerald Insight, XXVI(9), pp. 2084-2106.

Robinson-Fayek, A. D. M. a. C. O., 2003. Measuring and Classifying Construction Field Rework: A Pilot Study, Alberta: Department of Civil and Environmental Engineering.

Royal Institute of British Architects, 2013. RIBA Plan of Work 2013. [Online] Available at: https://www.ribaplanofwork.com/PlanOfWork.aspx

Ryan, G., 2018. Introduction to positivism, interpretivism and critical theory. Nurse Researcher, pp. 14-20.

Schatz, E., 2012. Rationale and procedures for nesting semistructured interviews in surveys or censuses. Population Studies, 66(2), pp. 183-195.

Schmidt, C., 2004. The Analysis of Semi-structured Interviews. In: U. Flick, E. V. Kardorff \& I. Steinke, eds. A Companion to Qualitive Research. London: SAGE Publications Ltd, pp. 253-258.

Sinclair, S. \& Rockwell, G., 2020. Voyant Tools. [Online] Available at: https://voyanttools.org/ [Accessed 28 January 2020].

Stahl, B. C., 2014. Interpretive accounts and fairy tales: a critical polemic against the empiricist bias in interpretive IS research. European Journal of Information Systems; Abingdon, pp. $1-11$.

Stasis, A., Whyte, J. \& Dentten, R., 2013. A Critical Examination of Change Control Processes. Procedia CIRP, pp. 177-182.

Tilacz, G., 2008. The Top Owners. Engineering News-Record Sourcebook, p. 8.

Trullols, E., Ruisanchez, I. \& Rius, X., 2004. Validation of qualitative analytical methods. TrAC Trends in Analytical Chemistry, 23(2), pp. 137-145.

Wates Ltd, 2020. Project Surveyor. [Online] Available at: https://wates.currentvacancies.com/Jobs/Advert/1886456?cid=1491\&s=False\&t=Project-

Surveyor\&l=Leeds [Accessed 14 March 2020].

Willmott Dixon Ltd, 2020. Quantity Surveyor. [Online] Available at: https://www.willmottdixon.co.uk/careers/job-search/view-job/quantity-surveyor1

[Accessed 14 March 2020].

Wouters, P., 2015. Bibliometrics. In: Ethics, Science, Technology, and Engineering: A Global Resource. Farmington Hills, MI: Macmillan Reference USA, pp. 204-206. 
Figure 1 - Process Flow Diagram for the Research Approach Adopted.

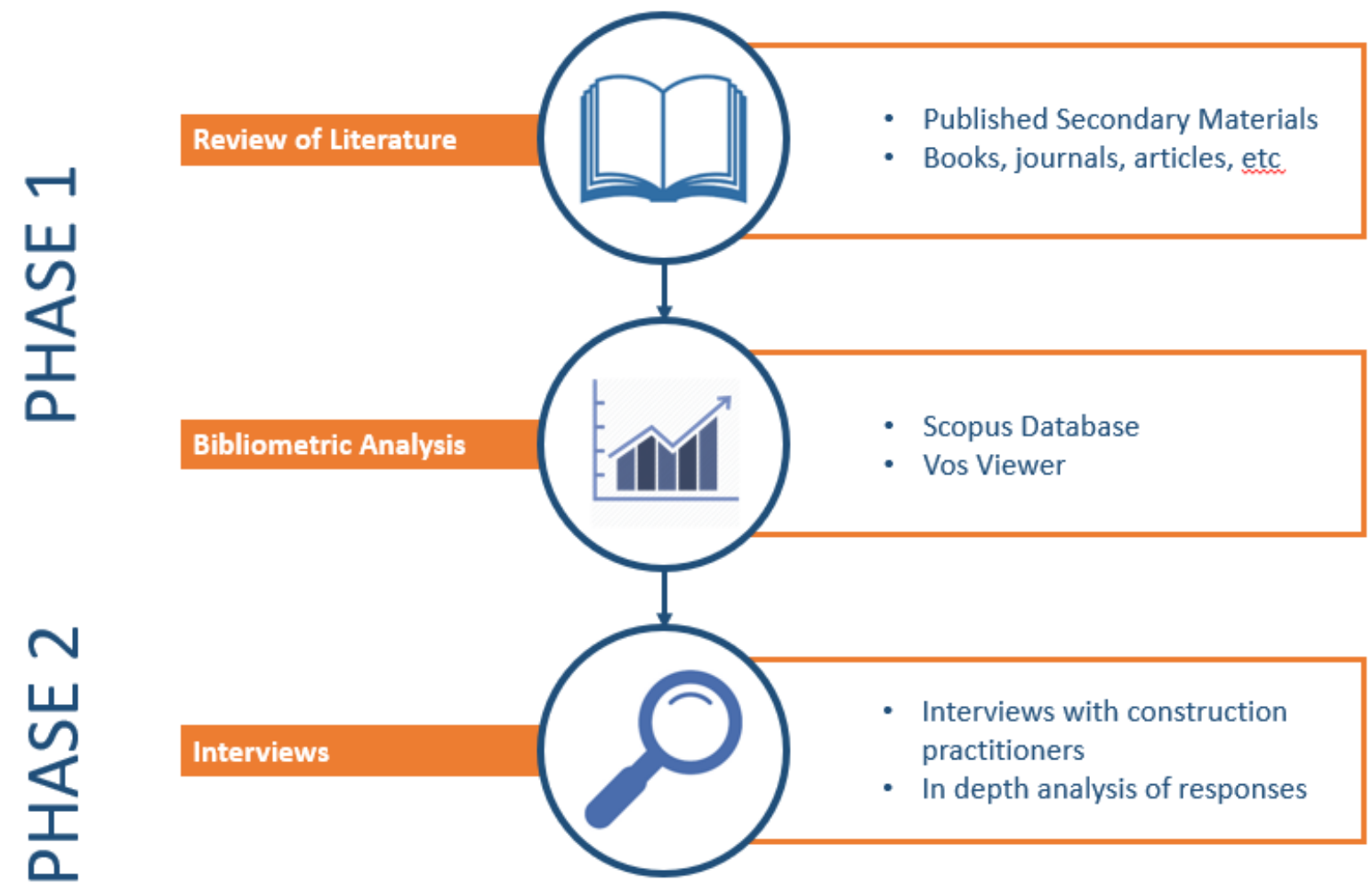


Figure 2 - RIBA Plan of Work Stages Demonstrated (Royal Institute of British Architects, 2013)
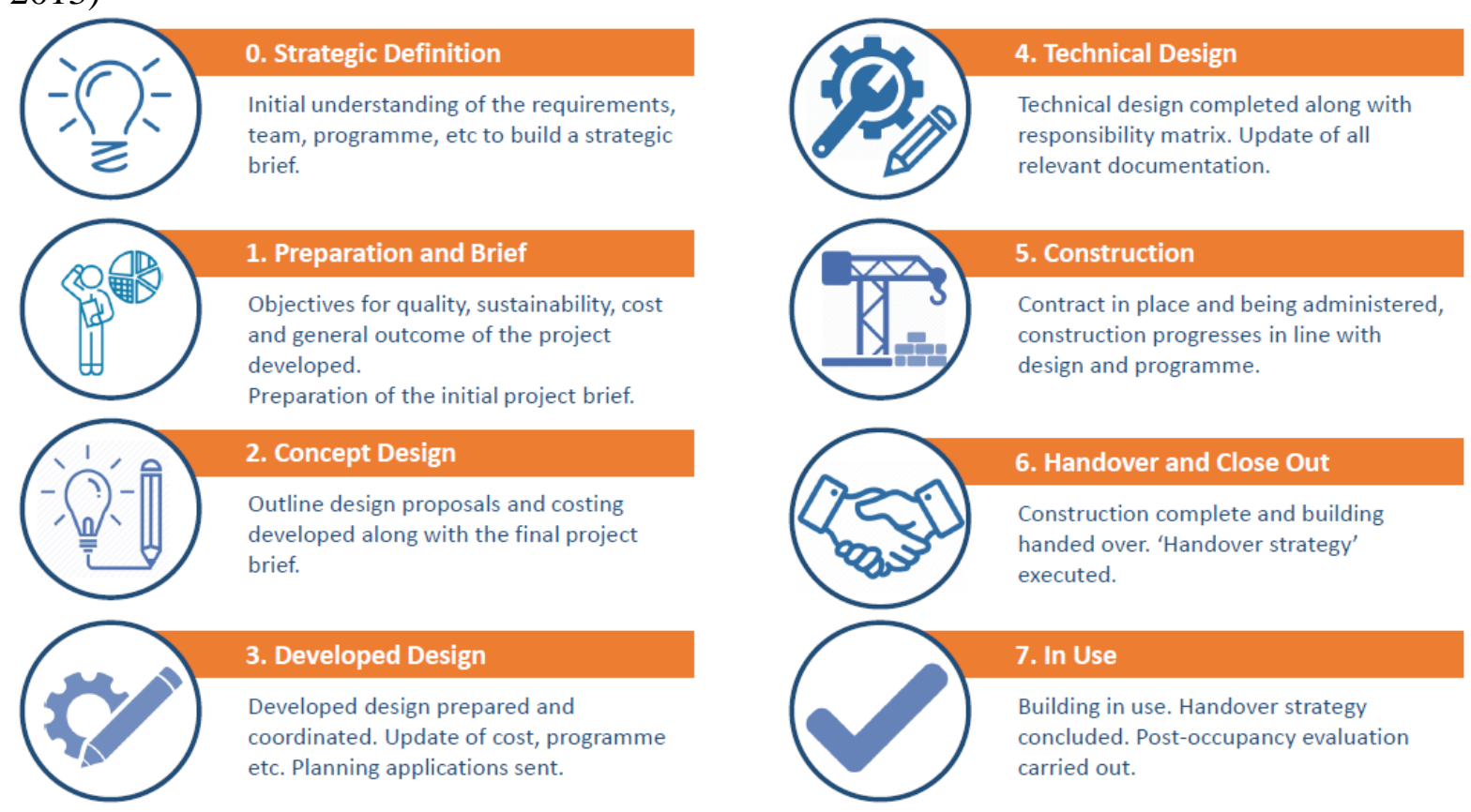
Figure 3 - Leading Authors in Change Management (CWTS, 2019)

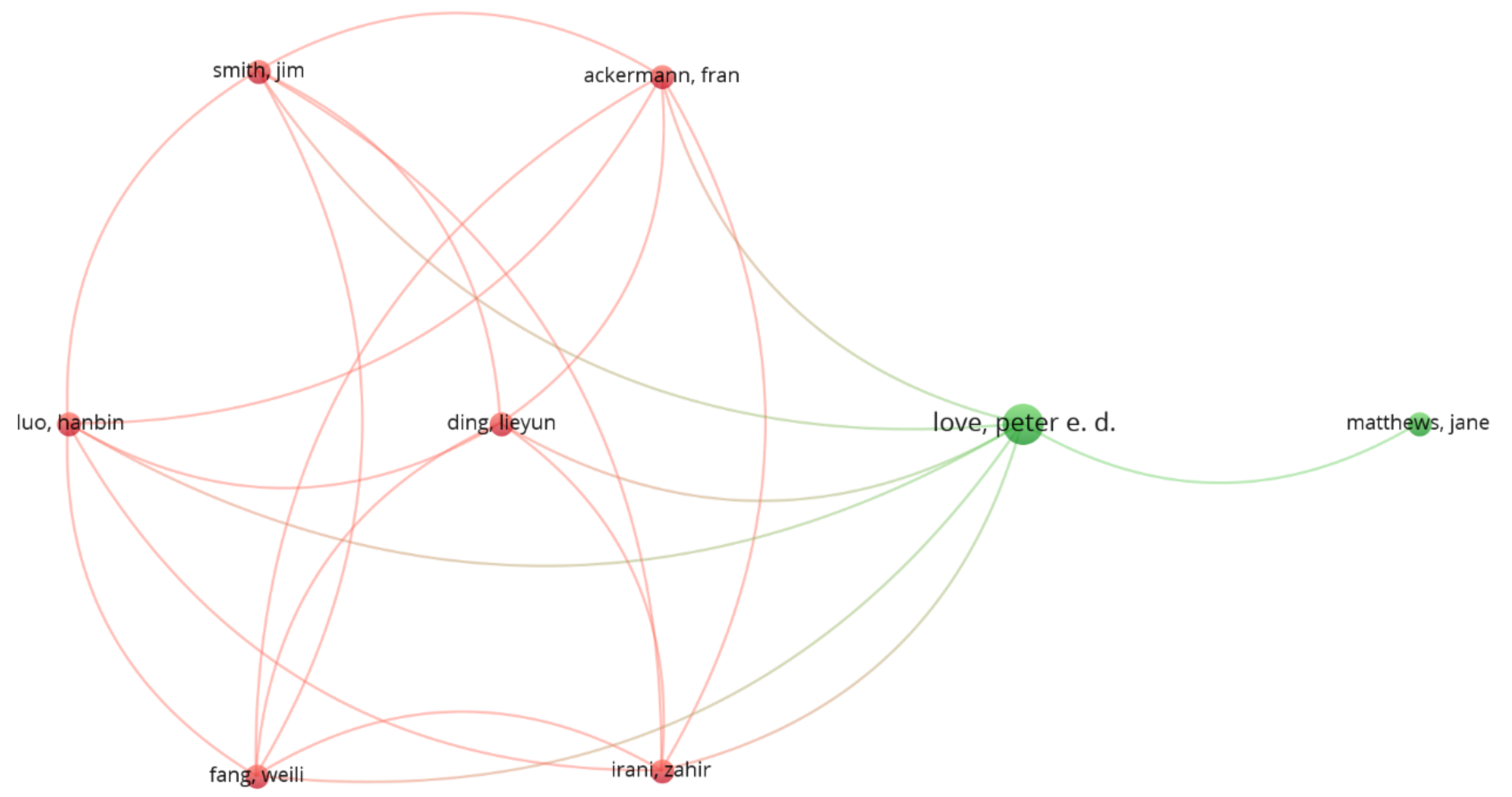

\& VOSviewer 
Figure 4-Web of Science Analysis of Construction Change Research Over Time

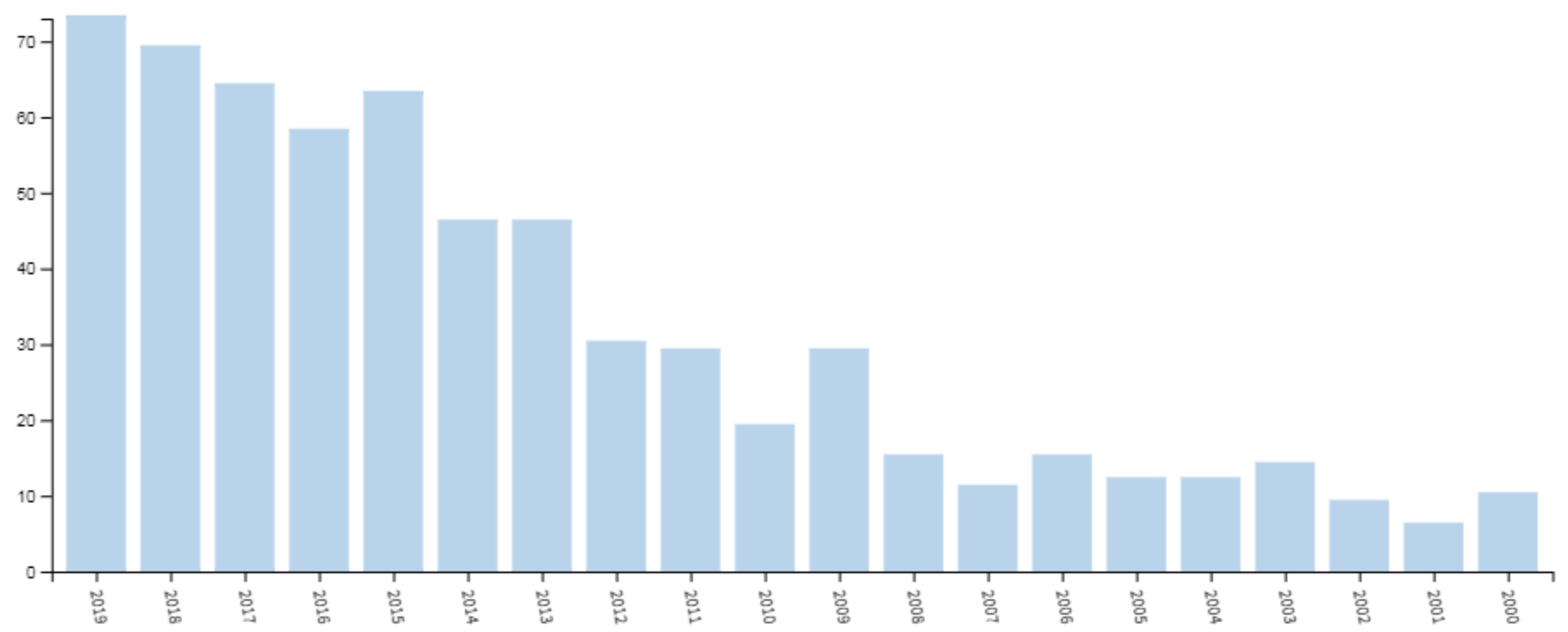


Figure 5 - Analysis of Key Terms of Construction Change Research with Fifty Occurrences (CWTS, 2019)

\& VOSviewer

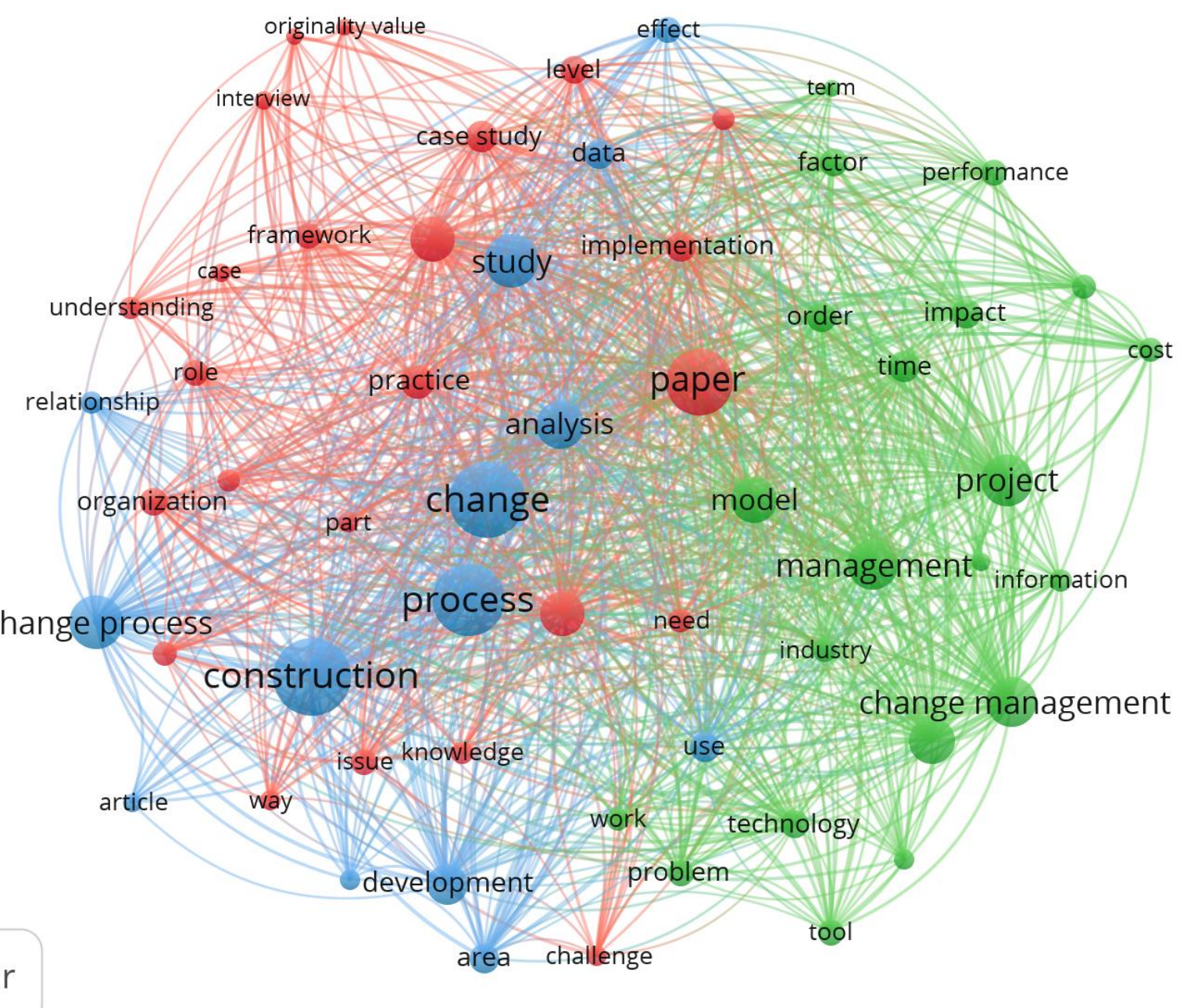


Figure 6 - Analysis of Key Terms of Construction Change Research with Ten Occurrences (CWTS, 2019)

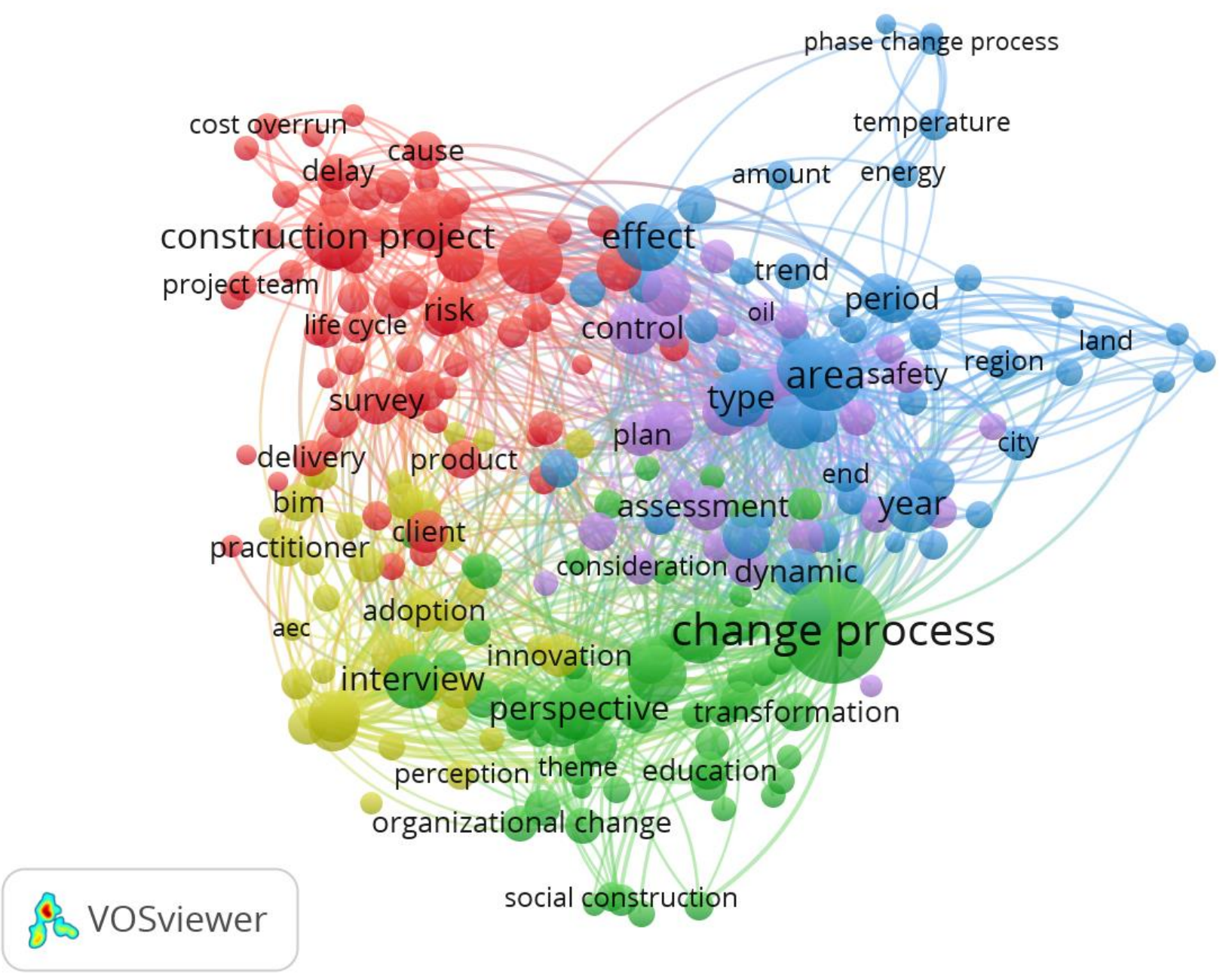


Figure 7 - Factors Affecting the Impact of Change with Frequency of Remarks

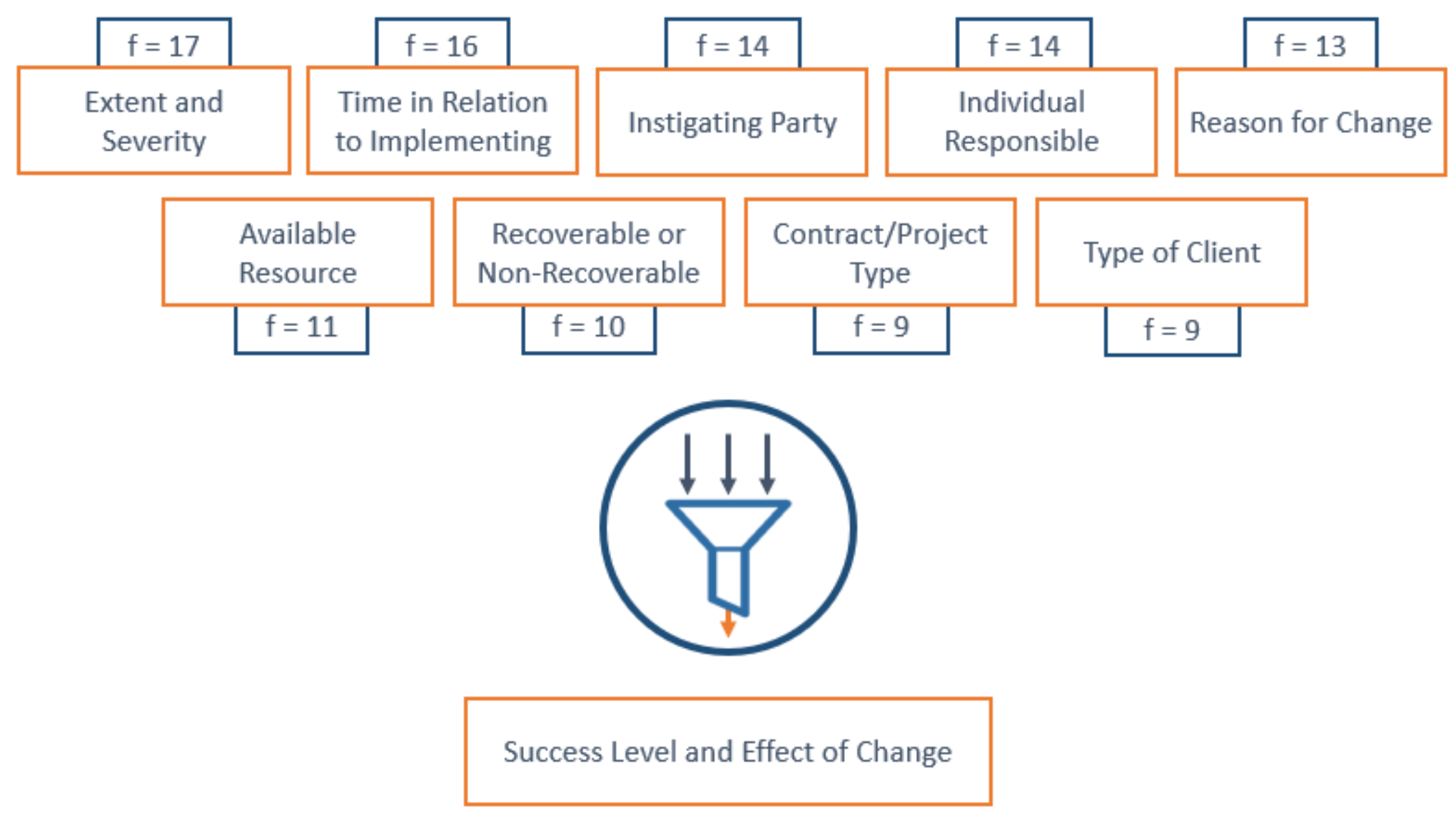


Figure 8 - Comparison of Overall Practitioners' Ranking of Parties' Control Over Change vs The Likelihood of Each Party to Initiate Change

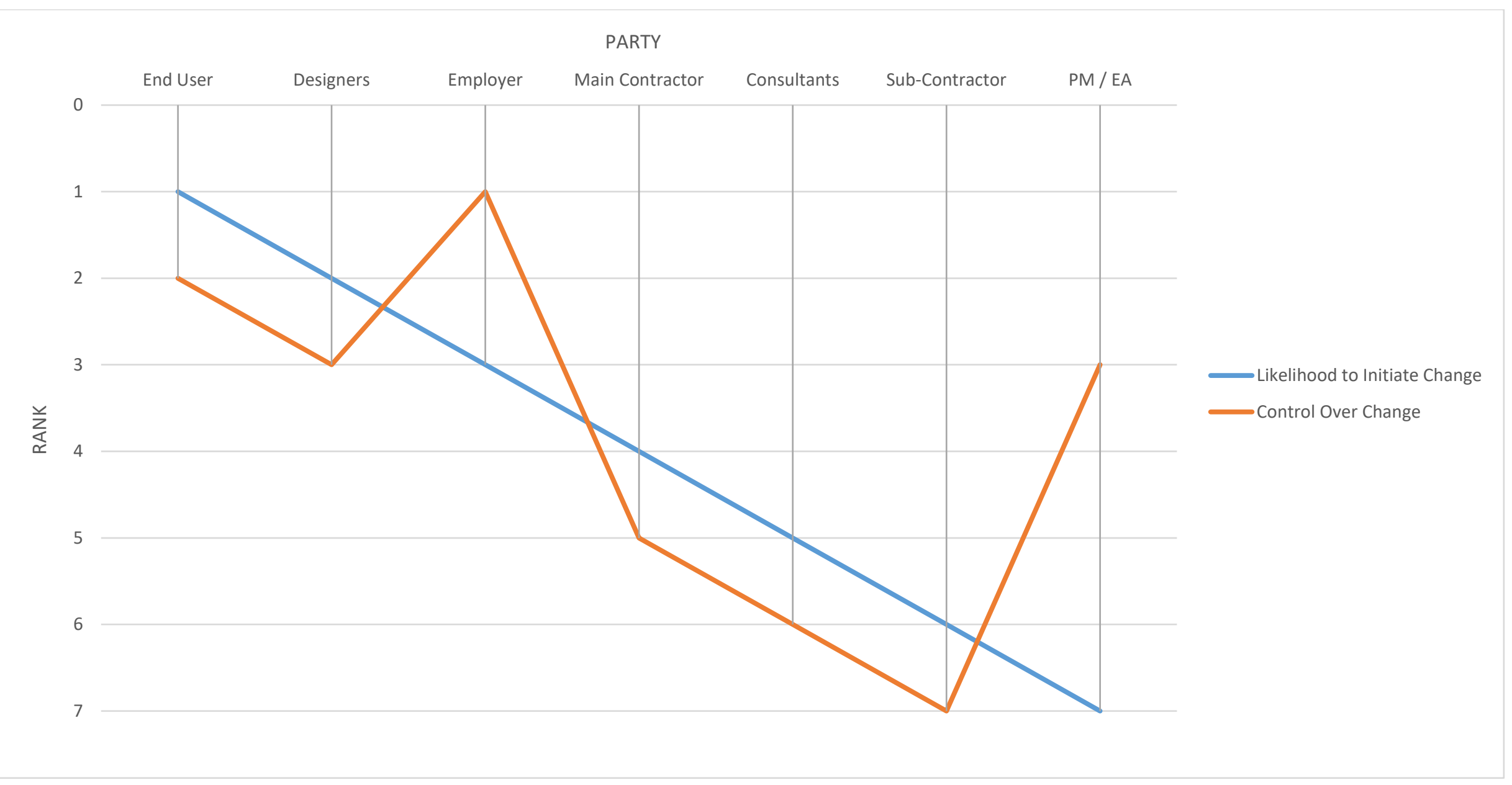


Figure 9 - Comparison of Overall Practitioners' Ranking of Importance vs The Effects Imposed by Change on Each Element

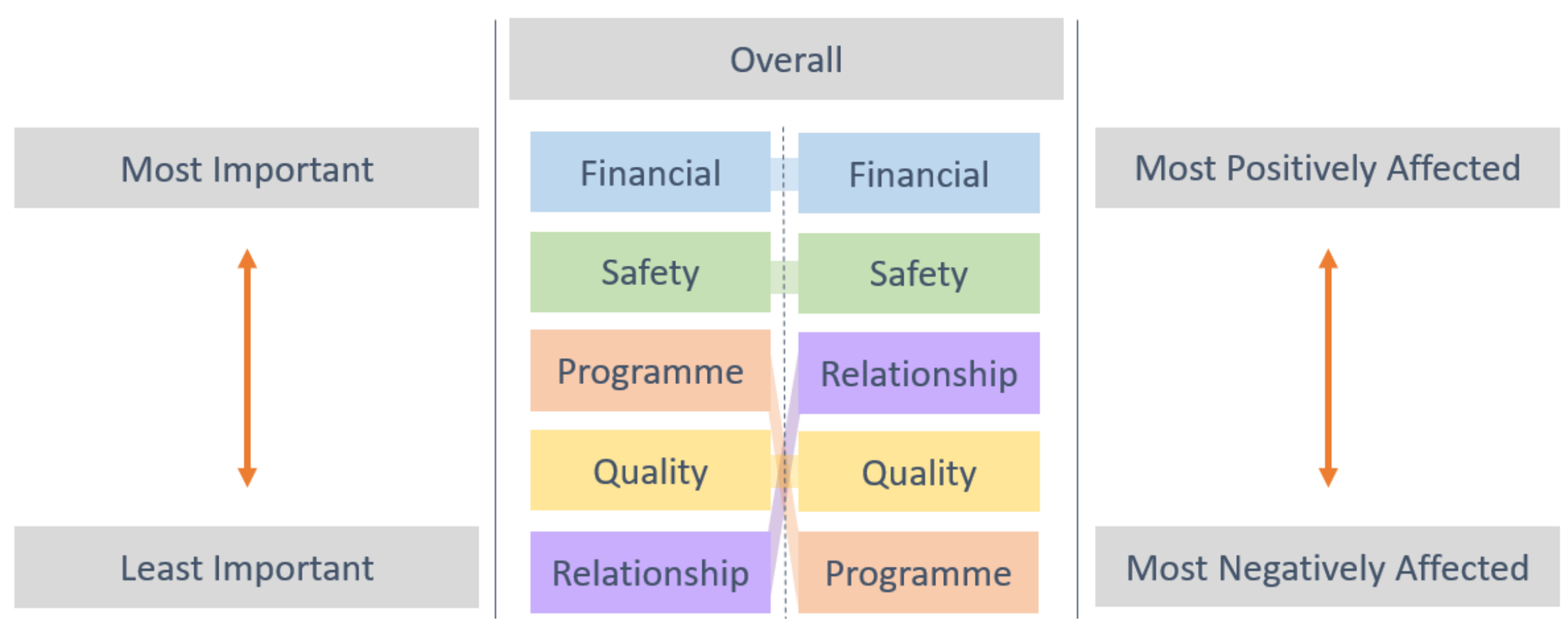


Table 1 - Definitions of Change

\begin{tabular}{|c|c|c|}
\hline Sector & Definition & Reference \\
\hline General & $\begin{array}{l}\text { "to exchange one thing for another thing" } \\
\text { "to make or become different" } \\
\text { "the act of becoming different, or the result of } \\
\text { something becoming different" }\end{array}$ & $\begin{array}{l}\text { (Cambridge Dictionary, } \\
2016)\end{array}$ \\
\hline Engineering & $\begin{array}{l}\text { Change is defined as any modification to elements, } \\
\text { drawings, software that were previously provided } \\
\text { during the design and production processes } \\
\text { regardless of the scale or type. }\end{array}$ & (Jarrett, et al., 2011) \\
\hline Construction & $\begin{array}{l}\text { A change constitutes and alteration to the scope, } \\
\text { period, cost and/or quality of the contracted works } \\
\text { A change to the Employer's Requirements, making } \\
\text { it necessary to alter the "design, quality or quantity } \\
\text { of the works". Including any additions, omissions or } \\
\text { substitutions of work. } \\
\text { Any obligations or restrictions imposed, added, } \\
\text { omitted or altered by the Employer with regards to } \\
\text { access, working space, hours or sequence of the } \\
\text { works. }\end{array}$ & $\begin{array}{l}\text { (Ibbs, 1997) } \\
\text { (Joint Contract Tribunal, } \\
\text { 2016) }\end{array}$ \\
\hline
\end{tabular}


Table 2 - Respondent Demographic

\begin{tabular}{|c|c|c|c|c|c|c|c|c|c|c|}
\hline \multirow[b]{2}{*}{ Ref } & \multirow[b]{2}{*}{ Job Title } & \multirow{2}{*}{ نُ } & \multirow{2}{*}{ 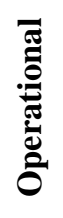 } & \multirow{2}{*}{ 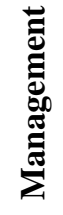 } & \multirow[b]{2}{*}{ Party } & \multicolumn{2}{|c|}{ Years of Experience } & \multicolumn{3}{|c|}{ Question Sets Answered } \\
\hline & & & & & & Industry & $\begin{array}{c}\text { Change } \\
\text { Management }\end{array}$ & General & Project & $\begin{array}{l}\text { Specific } \\
\text { Change }\end{array}$ \\
\hline $\mathrm{R} 1$ & Quantity Surveyor & $X$ & & & Main Contractor & 4.5 & 4.5 & $X$ & & \\
\hline $\mathrm{R} 2$ & Project Manager & & $\mathrm{X}$ & & Main Contractor & 19 & 9 & $\mathrm{X}$ & $\mathrm{X}$ & \\
\hline $\mathrm{R} 3$ & Project Director & & $\mathrm{X}$ & & Main Contractor & 34 & 28 & $\mathrm{X}$ & $\mathrm{X}$ & $\mathrm{X}$ \\
\hline $\mathrm{R} 4$ & Senior Quantity Surveyor & $\mathrm{X}$ & & & Main Contractor & 35 & 20 & $\mathrm{X}$ & $\mathrm{X}$ & $\mathrm{X}$ \\
\hline $\mathrm{R} 5$ & Quantity Surveyor & $\mathrm{X}$ & & & Sub-Contractor & 16 & 16 & $X$ & $X$ & \\
\hline R6 & Quantity Surveyor & $\mathrm{X}$ & & & Main Contractor & 8 & 8 & $\mathrm{X}$ & $\mathrm{X}$ & $\mathrm{X}$ \\
\hline R7 & Project Manager & & $\mathrm{X}$ & & Main Contractor & 47 & 31 & $X$ & $\mathrm{X}$ & $\mathrm{X}$ \\
\hline $\mathrm{R} 8$ & Senior Consultant & & & $\mathrm{X}$ & Dispute Resolution Consultant & 39 & 35 & $\mathrm{X}$ & & \\
\hline R9 & $\begin{array}{l}\text { Mechanical Electrical } \\
\text { Commercial Manager }\end{array}$ & $\mathrm{X}$ & & & Main Contractor & 44 & 40 & $\mathrm{X}$ & & \\
\hline $\mathrm{R} 10$ & Commercial Director & & & $\mathrm{X}$ & Main Contractor & 30 & 30 & $\mathrm{X}$ & & \\
\hline R11 & Managing Director & & & $\mathrm{X}$ & Developer & 34 & 29 & $X$ & & \\
\hline \multirow[t]{2}{*}{$\mathrm{R} 12$} & $\begin{array}{l}\text { Project Management } \\
\text { Quantity Surveyor }\end{array}$ & $\mathrm{X}$ & & & Client's Agent & 13 & 12 & $\mathrm{X}$ & $\mathrm{X}$ & $\mathrm{X}$ \\
\hline & TOTAL & 6 & 3 & 3 & & 323.5 & 262.5 & 12 & 7 & 5 \\
\hline
\end{tabular}




\begin{tabular}{|c|c|c|c|}
\hline & Commercial Response & Operational Response & Management Response \\
\hline $\begin{array}{l}\text { What is your opinion of change } \\
\text { occurring during the } \\
\text { construction phase of a } \\
\text { project? Have these } \\
\text { experiences been positive or } \\
\text { negative? }\end{array}$ & $\begin{array}{l}\text { Change can be an opportunity to generate margin growth; } \\
\text { however, it can be difficult to recover the programme } \\
\text { implications. This can result in the additional work putting } \\
\text { strain on quantity surveyors and other practitioners managing } \\
\text { the change. } \\
\text { The positive or negative effect of the change is largely } \\
\text { dependent on the point at which the change is instigated, the } \\
\text { type of contract and the type of work being altered. The earlier } \\
\text { a change is dealt with the better the outcome will be for all } \\
\text { parties since more time is available to assess the impact. }\end{array}$ & $\begin{array}{l}\text { Change is considered a mixture of positive and negative. The } \\
\text { positives are that change provides the opportunity for the design to } \\
\text { be developed, improving the quality of the product. } \\
\text { The point in time where the change is encountered determines the } \\
\text { effect. Where work is carried out before a change is imposed, } \\
\text { causing rework, it was considered that change was negative and } \\
\text { became difficult to gain buy in from the parties involved. }\end{array}$ & $\begin{array}{l}\text { Change can be used to mitigate onsite problems but often have the negative } \\
\text { effect of causing problems with regards to delays, disruptions, added costs } \\
\text { and the potential for dispute. } \\
\text { Change is inevitable and whilst this can provide a beneficial impact on } \\
\text { relationships through added communication, often a negative impact is seen } \\
\text { on the quality of the product. } \\
\text { An important factor which can often be missed is ensuring every change, no } \\
\text { matter how small, is tracked and defined as to what point of the process said } \\
\text { change is experienced with regards to the works. } \\
\text { For a main contractor or sub-contractor, change is an opportunity to "claw } \\
\text { back" money where low margins are set in the contract sum. For a developer } \\
\text { or client on the other hand, change can be problematic due to the financial } \\
\text { impacts: "the cost of change outweighs the benefit". }\end{array}$ \\
\hline $\begin{array}{l}\text { In your experience, what do } \\
\text { you consider are the main } \\
\text { causes for change during the } \\
\text { construction stage? }\end{array}$ & $\begin{array}{l}\text { The main cause of change is defined as end user or client } \\
\text { driven changes, this can be due to a change of mind, change of } \\
\text { requirements or a misunderstanding of the design. It was noted } \\
\text { that discrepancies, design errors, lack of information can all } \\
\text { drive change as well as change from the contractor or sub- } \\
\text { contractors which is generally lead by financial or programme } \\
\text { betterment. }\end{array}$ & $\begin{array}{l}\text { The drivers of change are incredibly varied, they are dependent on } \\
\text { the type of client and their needs and resources as well as the stage } \\
\text { of the project. In the early stages of construction, changes are } \\
\text { instigated to improve the financial position, later in the construction } \\
\text { phase, changes are often due to the client changing their } \\
\text { requirements. Overall it was deemed that change is mostly client or } \\
\text { end user lead. The end user tends to come onboard towards the end } \\
\text { of a project and drive change to ensure the product is suitable for its } \\
\text { intended use; this can be because of the designers misinterpreting } \\
\text { the requirements or that the requirements have altered. }\end{array}$ & $\begin{array}{l}\text { The causes of change are mostly client driven. A gap between the designer's } \\
\text { and client's understanding commonly leads to change being instigated as the } \\
\text { works develop and the design comes into fruition, providing the opportunity } \\
\text { for clients to reassess their requirements, or in other scenarios, the } \\
\text { requirements may develop meaning the design must follow. This is } \\
\text { commonly due to inadequacies in the early stages of the project, this can be } \\
\text { from the client providing a poor or incomplete brief; through a } \\
\text { misunderstanding of the employer's requirements or practicalities from the } \\
\text { designers; or through a poor or inadequate design being produced. } \\
\text { It was also discussed that change can be the result of innovation from the } \\
\text { contractor, usually for a financial benefit. }\end{array}$ \\
\hline $\begin{array}{l}\text { In your experience, what are } \\
\text { the effects of change during the } \\
\text { construction stage on the day- } \\
\text { to-day activities carried out by } \\
\text { you or those closely involved in } \\
\text { the change? }\end{array}$ & $\begin{array}{l}\text { The effects of change during the construction phase are } \\
\text { dependent on the extent of the change but changes always } \\
\text { impose additional workload on the commercial team. From } \\
\text { informing the client of the change and assessing the feasibility, } \\
\text { to assessing the cost and whether it is recoverable or not, } \\
\text { understanding the programme, quality and buildability } \\
\text { implications, whilst being careful not to strain relationships, } \\
\text { the management of change is a time-consuming process for } \\
\text { quantity surveyors working for a client, contractor or sub- } \\
\text { contractor. It was estimated that between } 30-60 \% \text { of a quantity } \\
\text { surveyor's time during the construction phase can be spent } \\
\text { managing change, making it a core part of the quantity } \\
\text { surveying role. } \\
\text { Formal instruction should be sought before carrying out the } \\
\text { works and, providing the change is deemed recoverable, it is } \\
\text { preferable for all parties if a cost can be agreed before } \\
\text { implementation to provide cost certainty; however, this can } \\
\text { often be difficult to achieve during the fast-moving } \\
\text { construction process. }\end{array}$ & $\begin{array}{l}\text { The first step for operational staff when a change is instructed is to } \\
\text { stop and assess the change and how best to manage it with the least } \\
\text { impact to those involved, the effect of that is that the programme } \\
\text { can become tighter due to the time spent managing the change. } \\
\text { The immediate effects of change during construction depend on } \\
\text { when the change is instructed in relation to when the work is due to } \\
\text { be carried out. The sooner a change is instructed, and the } \\
\text { assessment, costing and design processes are carried out, the less } \\
\text { impact the change will have on the operational progress. When a } \\
\text { change is implemented late in the process, it can cause confusion on } \\
\text { site and stress to those managing the project. It was noted that } \\
\text { change can be helpful to a contractor or sub-contractor with regards } \\
\text { to programme in instances where the programme is running behind, } \\
\text { a change can be an opportunity to regain time. }\end{array}$ & $\begin{array}{l}\text { Change can have a highly disruptive effect on day-to-day planned activities } \\
\text { as well as the overall programme. It can lead to disagreements over risk } \\
\text { allocation and what the original intent was against what is taking place } \\
\text { onsite which can be damaging to relationships. Change can provide an } \\
\text { opportunity for main contractors and sub-contractors to soak up their own } \\
\text { delays by reclaiming time associated with a recoverable change. } \\
\text { The importance of capturing change before the works commence onsite, } \\
\text { preventing abortive works, was highlighted due to the belief that rework } \\
\text { causes demotivation, which leads to lower quality on the second application. } \\
\text { An example of a successful change management process was provided from } \\
\text { a project where the employer's agent worked closely with the main } \\
\text { contractor's design and production team to provide design freeze deadlines, } \\
\text { demonstrating when sections of the project could no longer be altered by the } \\
\text { client or end user without significant cost impacts. Quantity surveyors have } \\
\text { an incredibly important role in tracking and managing change throughout } \\
\text { the construction process, and in the case of managing the design freeze } \\
\text { dates, the project manager would also have a key role in ensuring the } \\
\text { deadlines provided were correct and the programme managed stringently. }\end{array}$ \\
\hline $\begin{array}{l}\text { What, in your experience, are } \\
\text { the effects of change which is } \\
\text { implemented during the } \\
\text { construction phase on the final } \\
\text { status of a project? (I.e. Time, } \\
\text { cost, quality, relationships, etc) }\end{array}$ & $\begin{array}{l}\text { The effects on the final status of a project were considered } \\
\text { subjective, depending on when the change occurred; the type } \\
\text { of change; which party instigated the change and the severity } \\
\text { of the change. It is important to communicate fully with the } \\
\text { client throughout to avoid shock and therefore damage to the } \\
\text { relationship at the end of the project; if a change is likely to be } \\
\text { detrimental to the completion date, it is important that the } \\
\text { client understands this beforehand and is provided with the } \\
\text { opportunity to reassess the importance of said change. } \\
\text { The commercial respondents commented that time was } \\
\text { generally the most difficult element to recover, leading the } \\
\text { additional works to often saturate the programme. It was } \\
\text { discussed that the total project cost almost always increases }\end{array}$ & $\begin{array}{l}\text { Operational practitioners explained that quality and relationships } \\
\text { should be maintained regardless of anything else changing; } \\
\text { however, this is dependent on the contractual route selected and the } \\
\text { strength of the relationship before and during the construction } \\
\text { process. It was discussed that by finishing a project on time, the } \\
\text { relationship should be maintained even in cases where the cost has } \\
\text { increased. }\end{array}$ & $\begin{array}{l}\text { Change can be a cause for delay to the project completion date, when a } \\
\text { change doesn't affect the critical path, it often still causes disruption. If fully } \\
\text { and correctly tracked, however, time can be recovered. The effect of this can } \\
\text { result in project milestones being missed and/or costs increasing such as } \\
\text { preliminaries thickening. The added pressure associated with change can } \\
\text { lead to the detriment of quality since time and resource often becomes } \\
\text { strained, or in instances where a change is applied to completed works, the } \\
\text { demotivation experienced can lead to lesser quality works being undertaken, } \\
\text { and this can ultimately lead to strained relationships. } \\
\text { On the contrary, change can lead to improved relationships if managed } \\
\text { effectively, since more interaction will be experienced. }\end{array}$ \\
\hline
\end{tabular}




\begin{tabular}{|c|c|c|c|}
\hline & $\begin{array}{l}\text { due to client-driven change which is sometimes a cause for } \\
\text { frail relationships. } \\
\text { Where client-driven change is seen, this is often instigated } \\
\text { with the intention to increase quality. However, from the } \\
\text { contractor's perspective, despite the intention to always } \\
\text { maintain relationships and quality, sometimes the strain } \\
\text { imposed on the time and cost can have negative effects on } \\
\text { these elements. }\end{array}$ & & \\
\hline $\begin{array}{l}\text { In your opinion, how well do } \\
\text { we manage change as an } \\
\text { industry? }\end{array}$ & $\begin{array}{l}\text { The commercial respondents present mixed views on how well } \\
\text { change is managed within the construction industry. Financial } \\
\text { implications tend to be captured well but the same proficiency } \\
\text { is not seen with regards to time and quality; the cause of this is } \\
\text { often due to the quantity surveyor leading the management of } \\
\text { the change with little operational input. The standard of the } \\
\text { change management is largely dependent on the individuals } \\
\text { dealing with the change from each party's perspective. }\end{array}$ & $\begin{array}{l}\text { Change management is considered a challenge, where sometimes } \\
\text { risks are taken to progress the works without instruction and based } \\
\text { on trust, which ends in a loss for the contractor. II was highlighted } \\
\text { that as an industry, cost is often recovered but time can be left } \\
\text { unrecovered, meaning there is a requirement to work harder and } \\
\text { longer to absorb delay. In instances where a change is made to } \\
\text { provide a financial benefit, often the change isn't fully considered } \\
\text { and has the opposite effect. Every construction project is a } \\
\text { prototype requiring full diligence and consideration when } \\
\text { implementing a change, since time and resource is often limited, it } \\
\text { can sometimes be unfeasible to carry out the assessments necessary } \\
\text { to ensure a change is fully planned. }\end{array}$ & $\begin{array}{l}\text { Competitively priced tenders, where risk allocation is heavily loaded against } \\
\text { contractors and thus the supply chain puts pressure on the parties, leading to } \\
\text { poor management of change. This can lead to ignorance of the full effects } \\
\text { whilst the focus remains on progressing with the works, which can be } \\
\text { detrimental. Each construction project is unique, requiring a bespoke } \\
\text { design, often these designs are produced by people with limited } \\
\text { understanding of construction processes, making it inevitable that design } \\
\text { errors and discrepancies will be encountered. There are occasions where } \\
\text { highly successful change management has been seen, an example was } \\
\text { provided of a project where significant levels of change were encountered. } \\
\text { A dedicated quantity surveyor was appointed by the main contractor to } \\
\text { manage each of the } 3,500 \text { changes from inception through to } \\
\text { implementation, including the design, buildability, cost, programme, quality } \\
\text { and relationship aspects. Adversely, there are many examples of projects } \\
\text { where the individuals responsible for managing the change unsure of which } \\
\text { changes have been instructed, designed, costed, etc. The success of change } \\
\text { management is dependent on the individuals responsible for dealing with the } \\
\text { change. }\end{array}$ \\
\hline $\begin{array}{l}\text { How could we improve on how } \\
\text { we manage change during the } \\
\text { construction stage? }\end{array}$ & $\begin{array}{l}\text { Developing strong lines of communication; understanding of } \\
\text { the processes to be undertaken from all parties from the outset; } \\
\text { and an agreement on time scales for the change management } \\
\text { process aids proper management of the change and longevity } \\
\text { of the relationships. It was noted that improved operational } \\
\text { input was critical to improved success and spending more time } \\
\text { during the design stage, ensuring the designs are correct and } \\
\text { buildable would improve the conditions during the } \\
\text { construction phase. }\end{array}$ & $\begin{array}{l}\text { Reducing the amount of change to as little as possible during the } \\
\text { construction phase would improve standards of change } \\
\text { management. Providing thorough, visual presentations to the client } \\
\text { and end user early in the process to bridge the gap between } \\
\text { expectation and reality would help reduce the level of change } \\
\text { occurring during construction. It was suggested that getting the } \\
\text { right parties involved in the early design stages, and the right } \\
\text { parties involved in assessing change during the construction phase } \\
\text { would improve change management processes. This would need to } \\
\text { be assessed on a case by case basis at the start of each project and at } \\
\text { the start of each change. }\end{array}$ & $\begin{array}{l}\text { Practices could be improved through minimising the amount of change to } \\
\text { manageable levels. Increasing the time spent at the start of a project to allow } \\
\text { more time to fully develop the brief and design would assist in change } \\
\text { minimisation. Partnering and strong relationships can drive better } \\
\text { understanding throughout the parties involved, leading to better practices. } \\
\text { Proper risk allocation, to the party most equipped to deal with each risk } \\
\text { rather than offsetting risk from one party to another to protect their own } \\
\text { interests would improve management of change as well as relationships. } \\
\text { Those dealing with change management should assess the full impacts of a } \\
\text { change at the earliest opportunity to avoid blind spots or unconsidered } \\
\text { effects. Thorough record keeping for each change is deemed essential. By } \\
\text { assessing the patterns of the volume of change instigated by common } \\
\text { clients, an assessment can be made by the main contractor as to the level of } \\
\text { resource to apportion to change management throughout the construction, } \\
\text { this would relieve the pressure from those who often spend a large portion of } \\
\text { their time managing change rather than completing their intended job role. }\end{array}$ \\
\hline
\end{tabular}


Table 4 - Analysis of Leading Contractors' Quantity Surveying Role Descriptions Taken from Contractor Websites

\begin{tabular}{|c|c|c|}
\hline Contractor & Terms Frequented $\geq 3$ Times & Reference \\
\hline $\begin{array}{l}\text { Balfour Beatty } \\
\text { Plc }\end{array}$ & $\begin{array}{l}\text { team: } 6 \text {; project: } 6 \text {; with: } 5 \text {; quantity: } 4 \text {; } \\
\text { ensure: } 4 \text {; all: } 4 \text {; projects: } 4 \text {; other: } 4 \text {; } \\
\text { members: } 4 \text {; } 4 \text {; relevant: } 4 \text {; work: } 3 \text {; } \\
\text { commercial: } 3 \text {; provide: } 3 \text {; surveying: } 3 \text {; } \\
\text { knowledge: } 3\end{array}$ & $\begin{array}{l}\text { (Balfour Beatty PLC, } \\
\text { 2020) }\end{array}$ \\
\hline $\begin{array}{l}\text { Morgan Sindall } \\
\text { Group }\end{array}$ & $\begin{array}{l}\text { sindall: } 5 \text {; quantity: } 4 \text {; work: } 4 \text {; for: } 4 \text {; } \\
\text { morgan: 4; people: } 4 \text {; knowledge: } 4 \text {; } \\
\text { surveyor: } 3 \text {; about: } 3 \text {; would: } 3 \text {; within: } 3 \text {; } \\
\text { infrastructure: } 3 \text {; industry: } 3 \text {; across: } 3 \text {; } \\
\text { commercial: } 3 \text {; contract: } 3 \text {; reporting: } 3 \text {; } \\
\text { experience: } 3 \text {; sub-contractors: } 3\end{array}$ & $\begin{array}{l}\text { (Morgan Sindall } \\
\text { Group, 2020) }\end{array}$ \\
\hline Kier Group & kier: 4; we: 3; you: 3; be: 3; your: 3 & (Kier Group Plc, 2020) \\
\hline $\begin{array}{l}\text { BAM Construct } \\
\text { UK }\end{array}$ & $\begin{array}{l}\text { working: } 7 \text {; for: } 5 \text {; project: } 4 \text {; experience: } 4 \text {; } \\
\text { professional: } 4 \text {; all: } 3 \text {; within: } 3 \text {; on: } 3 \text {; } \\
\text { procurement: } 3 \text {; subcontract: } 3 \text {; packages: } 3 \text {; } \\
\text { final: } 3 \text {; accounts: } 3 \text {; client: } 3 \text {; team: } 3\end{array}$ & $\begin{array}{l}\text { (BAM Construct UK, } \\
\text { 2020) }\end{array}$ \\
\hline Laing O’Rourke & for: 6 ; you: 5 ; commercial: 4 ; mep: 3 ; your: 3 & $\begin{array}{l}\text { (Laing O'Rourke, } \\
\text { 2020) }\end{array}$ \\
\hline Galliford Try & subcontract: 4; will: 3 ; dates: 3; with: 3 ; & (Galliford Try \\
\hline Holdings & experience: 3 ; you: 3 ; would: 3 & Holdings plc, 2020) \\
\hline Wates Ltd & $\begin{array}{l}\text { will: } 6 \text {; project: } 5 \text {; reports: } 4 \text {; with: } 4 \text {; for: } 3 \text {; } \\
\text { surveyor: } 3 \text {; team: } 3 \text {; you: } 3 \text {; strategies: } 3 \text {; } \\
\text { commercial: } 3 \text {; ability: } 3\end{array}$ & (Wates Ltd, 2020) \\
\hline $\begin{array}{l}\text { Willmott Dixon } \\
\text { Ltd }\end{array}$ & $\begin{array}{l}\text { with: } 10 \text {; you: } 7 \text {; for: } 7 \text {; we: } 6 \text {; our: } 6 \text {; project: } \\
\text { 6; your: } 6 \text {; be: } 5 \text {; projects: } 5 \text {; work: } 5 \text {; } \\
\text { working: } 4 \text {; that: } 4 \text {; willmott: } 4 \text {; dixon: } 4 \text {; } \\
\text { will: } 4 \text {; new: } 3 \text {; demonstrate: } 3 \text {; experience: } 3 \text {; } \\
\text { team: } 3 \text {; contract: } 3 \text {; conditions: } 3 \text {; accurately: } \\
3 \text {; appropriate: } 3 \text {; this: } 3\end{array}$ & $\begin{array}{l}\text { (Willmott Dixon Ltd, } \\
\text { 2020) }\end{array}$ \\
\hline
\end{tabular}

Source: Public records. 
Appendix 1 - Interview Questions

\section{Demographic (All respondents)}

What is your role?

How many years' experience do you have in the industry?

How many years' experience do you have in dealing with construction project change management?

\section{Change - General (All respondents)}

1. Please rate the level of effect 'change' during the construction phase generally has on each of the following elements. Then, please rank each of the elements based on importance from 1-5 where 1 is most important and 5 is least important with regards to construction project change:

\begin{tabular}{|c|c|c|c|c|c|c|}
\hline Elements & 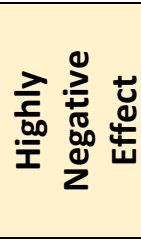 & 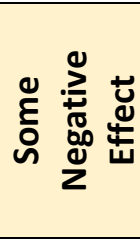 & 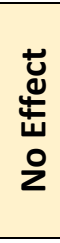 & 总 & 空 & $\begin{array}{c}\text { Rank } \\
\text { (1 = Most } \\
\text { important; } \\
5 \text { = Least } \\
\text { important) }\end{array}$ \\
\hline \multicolumn{7}{|l|}{ Programme } \\
\hline \multicolumn{7}{|l|}{ Financial } \\
\hline \multicolumn{7}{|l|}{ Quality } \\
\hline \multicolumn{7}{|l|}{ Safety } \\
\hline Relationships & & & & & & \\
\hline
\end{tabular}

2. Please rate (in general terms) how often the following parties instigate change during the construction stage. Then please rank in terms of which party has the most control (1) to least control (7):

\begin{tabular}{|c|c|c|c|c|c|c|}
\hline Party & $\frac{\text { dे }}{\text { ¿ }}$ & 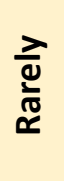 & 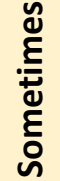 & 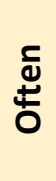 & $\frac{n}{\frac{n}{\pi}}$ & $\begin{array}{c}\text { Rank } \\
\text { (1 = Most control; } \\
7=\text { Least control) }\end{array}$ \\
\hline Main Contractor & & & & & & \\
\hline Sub-Contractors & & & & & & \\
\hline Designers & & & & & & \\
\hline Employer & & & & & & \\
\hline End User & & & & & & \\
\hline Project Manager & & & & & & \\
\hline Consultants & & & & & & \\
\hline
\end{tabular}




\section{Change-General Continued}

In general terms:

6. What is your opinion of change occurring during the construction phase of a project? Have these experiences been positive or negative?

7. In your experience, what do you consider are the main causes for change during the construction stage?

8. In your experience, what are the effects of change during the construction stage on the day-today activities carried out by you or those closely involved in the change?

9. What, in your experience, are the effects of change which is implemented during the construction phase on the final status of a project? (le. Time, cost, quality, relationships, etc)

10. From your understanding, what is the formal process under the JCT for managing a change which is initiated by the Employer?

11. In your opinion, how well do we manage change as an industry?

12. How could we improve on how we manage change during the construction stage?

\section{Change - Specific Project (Project Team Only)}

With reference to Project $X$ :

1. From your perspective, was change during the construction stage of the project positive or negative? Why?

2. From your perspective, what were the main causes for change during the construction stage?

3. From your perspective, what were the effects of change during the construction phase on the day-to-day activities carried out by you or those closely involved in the change?

4. What do you think were the effects of the changes implemented during the construction phase on the final status of the project (ie time, cost, quality, relationships, safety, etc)?

5. If you were to start the project from scratch again, is there anything you would do differently with regards to change management?

\section{Specific Change (Specific Project Team Members Only)}

With reference to $E I 44.01$ for the addition of windows in rooms $X$ and $X$ :

1. Please explain the cause and reason for the change;

2. Please explain the work involved in executing the change;

3. Please explain the effects that this specific change had on time, cost, quality and relationships during construction;

4. Please explain the effects this specific change had on the parties (ie. End user, Employer, $\mathrm{PM} / \mathrm{PQS}$, Main contractor, Sub-contractors, Designers);

5. What was the process of reporting, managing, monitoring this change? 
6. How successful was this change? Why?

7. If you were to start the project from scratch again, is there anything you would do differently with regards to this specific change? Why?

Thank you for taking the time to participate in this interview. 
Appendix 2 - Change Management Guidance Model

\title{
Change Management Guidance Model Part 1: Focus on Change Management
}

\author{
When to be used: During teaching, training and employment \\ To be used by: Construction companies; educational facilities \\ Consultation required with: Employees managing construction project change
}

\section{Outline:}

Change management during the construction stage of a project is a key element of the quantity surveying role. As a major factor affecting the outcome of any project, change management should also form a key part of the project operations team's roles. By providing increased focus on change management during education, at the point of employment and during training, increased focus and proficiency should be seen when managing change.

\section{Key Steps to be Taken:}

1. Educational facilities, such as universities delivering construction management and quantity surveying courses, should include 'Change Management in Practice' as a teaching topic, covering the following key elements:

a. Causal factors of change and how to manage them

b. Key elements affecting the outcome of change

c. Knock-on effects of change instigated during the construction stage on (1) day-today responsibilities; (2) other interfacing elements of construction and (3) the overall success of a project.

2. Construction companies, when hiring for construction management and quantity surveying roles, to include change management as a core part of the role.

3. Construction companies to provide training and support for change management to construction management and quantity surveying roles.

Intended Outcome:

Through highlighting the importance of change management, particularly in the context of an individual's specific job role, an increased focus on the management of change should be seen and improved outcomes of change sought. 


\title{
Change Management Guidance Model Part 2: Project Brief Definition
}

\author{
When to be used: During RIBA stages 0-1 \\ To be used by: Employer/Client \\ Consultation required with: End user; designers; consultants; contractor
}

\section{Outline:}

The brief should be well considered and as thorough as possible, using available knowledge and resources from a global perspective. Support should be sought to define the requirements and ensure clarity.

Key Steps to be Taken:

1. Employer / Client to define what resources are available to them

2. Employer / Client to define what elements are most important to them, including but not limited to the following:
a. Time / Cost / Quality - maximum of two to be stated
b. Minimal risk or control over the project - one to be stated
c. What is the project?
d. Why is it being developed?
e. How will the project integrate with the local area?
f. When is the project intended to commence and complete?

3. Employer/Client to engage end user (or reflective sample of end users if not known) to understand their requirements

4. Employer/Client to consult with designers to understand what information they require to be able to produce a design

5. Employer/Client to develop the brief, including the requirements of the end user and satisfying the requirements of the designers, providing as much detail as possible

6. Once the brief is issued to the designers, a 'Brief Review Session' is to be held between Employer/Client, designers, contractor and, if deemed necessary, the employer's agent/project manager to ensure the brief is:

a. Communicated and understood by all parties

b. Thoroughly considered to account for design and operational implications

7. Following the review session, the design is to commence - see 'Part 3: Design Development'

8. When later tendering the project to contractors, the minutes of the review meeting should be distributed and discussed to ensure the requirements are clear.

\section{Intended Outcome:}

Through providing a thoroughly considered and communicated brief, the likelihood of a gap in understanding or misinterpretation of the requirements is minimised. 


\title{
Change Management Guidance Model Part 3: Design Development
}

\author{
When to be used: During RIBA stages 2-4 \\ To be used by: Designers \\ Consultation required with: End user; employer/client; consultants; contractor
}

\section{Outline:}

The design should be well considered and as thorough as possible, ensuring compliance with not only the employer/client's brief, but with their expectations. The design should be developed using the knowledge and resources available, considering buildability as a key factor and ensuring clarity.

Key Steps to be Taken:

1. Designer to ensure full understanding of the employer/client's requirements, priorities and expectations

2. Designer to ensure full understanding of the end user's requirements, priorities and expectations

3. Designer to develop the design in line with the project brief, with particular attention on the elements deemed most important to the employer/client and end user

4. Designer to consult with contractors to understand what information they require to be able to produce a price and assess buildability

5. Designer to develop the design, including the requirements of the end user and employer/client, including the information required by the contractor(s), providing as much detail as possible

6. Once the design is issued to the employer/client, a 'Design Review Session' is to be held between designer; employer/client, contractor and, if deemed necessary, the employer's agent/project manager to ensure the design is:
a. Reflective of the requirements, priorities and expectations of the employer/client and end user
b. Thorough enough to price
c. Buildable
d. Communicated and understood by all parties

7. When later tendering the project, the minutes of the review meeting should be distributed and discussed to ensure the requirements are clear.

Intended Outcome:

Through providing a thoroughly considered and communicated design, the likelihood of a gap in understanding or misinterpretation of the requirements is minimised. 


\title{
Change Management Guidance Model Part 4: Main Contract Set-Up
}

\author{
When to be used: When about to award main contract and enter RIBA \\ stage 5
}

To be used by: Employer/client; employer's agent/project manager

Consultation required with: Contractor; designer; consultants; sub-contractors

\section{Outline:}

The construction product should match the design and the design should meet the employer/client's brief and expectations. To limit the risk of misunderstanding and minimise overloading a single party with undue liability, the parties should revisit the requirements and ensure aligned expectations.

Key Steps to be Taken:

1. Review meeting to be held between the employer/client, employer's agent/project manager, designers, contractor and any other parties deemed essential. Within this meeting the following non-exhaustive list should be discussed:

a. The original brief in comparison to the latest design and contract information, using the minutes from the 'Brief Review Session' and 'Design Review Session' for reference:

i. Are the requirements, priorities and expectations understood?

ii. Are they being met by the design?

iii. Are they being met by the descriptions within the contract?

b. The latest design information, using the minutes from the 'Design Review Session' for reference:

i. Is it buildable?

ii. Is it clear to the employer/client what is being built?

iii. Is it clear to the contractor what is required?

iv. Is it clear to the employer/client and end user how the product will function?

c. Risk allocation:

i. What are the project risks?

ii. Which party is best equipped to manage each risk?

iii. Has the party best equipped to manage each risk been allocated to do so within the contract? If not, why?

2. Employer's agent/project manager to ensure the requirements are captured and any revisions required to the information is completed and communicated clearly to the parties

Intended Outcome:

Through ensuring the requirements, priorities and expectations of the employer/client and the end user are met within the design and contract, the likelihood of misinterpretation of the requirements and change occurring is minimised. Correctly allocated risk prevents overloading one party, allowing the project team to work to a common goal rather than focusing on risk mitigation. 


\title{
Change Management Guidance Model Part 5: Construction Stage
}

\author{
When to be used: During RIBA stage 5; upon award contract \\ To be used by: Contractor \\ Consultation required with: Employer/client; employer's agent/project manager; \\ designer; consultants; sub-contractors
}

\section{Outline:}

There are nine key factors affecting the outcome of change and how positively or negatively the main elements of a project (quality, cost, time, relationships) are impacted. Communication of these affecting factors along with a clear change management process should provide an improved experience and outcome.

Key Steps to be Taken:

1. Contractor to communicate the nine key affecting factors of change to the parties, explaining that assessment of these factors should be considered before initiating any change:

a. Extent and severity of the change - how big/challenging/impactful is the change?

b. Time in relation to implementing the change - how much time is there to assess the implications of the change and communicate to the operatives? Will the change mean rework for the operatives?

c. Instigating party - who has initiated the change? Are they able to take responsibility for the change? Do they understand the impacts?

d. Individual(s) responsible for managing the change - Who is responsible for assessing, tracking, managing, implementing the change? Are they capable? Do they have the required resources?

e. Reason for the change - Is the change necessary? Considering the other affecting factors, is the change worth the potential detriment?

f. Available resource - Is there available resource from the client, design, commercial and operational teams to assess the change and its impact before implementing?

g. Recoverable or non-recoverable - Is the change recoverable to those carrying it out? Is the recoverability status clear to all relevant parties?

h. Contract / project type - What type of contract is used? Is the project traditional, design and build, other? What is the contract's prescribed process for change management?

i. Type of client - Who is the employer/client? Are they experienced in construction project change management? Do they understand the potential implications of change on time, cost, quality, relationship, etc?

2. Contractor to ensure suitable person is allocated as responsible for managing change, including but not limited to the following duties:

a. Record the change: What is it? Date initiated? Is it designed? Is it instructed? Will it impact cost? Will it impact time? Has the client been notified of the impacts? 
b. In line with points $1 a-1 i$ above, assess the status of the change with input from client, design, commercial and operational representatives

c. Liaise with the relevant parties from the supply chain and employer/client team to ensure clarity of the requirements and the effects

3. Contractor to ensure operational staff are able and willing to input in the assessment and management of change

4. Contractor to work with the designers and supply chain to define design freeze dates for each element of the build. These dates and areas are to be communicated to the project team to promote the limitation of change initiation to the suitable periods only.

\section{Intended Outcome:}

Through ensuring the potential effects and key affecting factors of change are communicated to the parties most likely to initiate change, the volume of change should be minimised. Change still deemed necessary should be implicated at a more optimal time, more refined and better managed. 
